
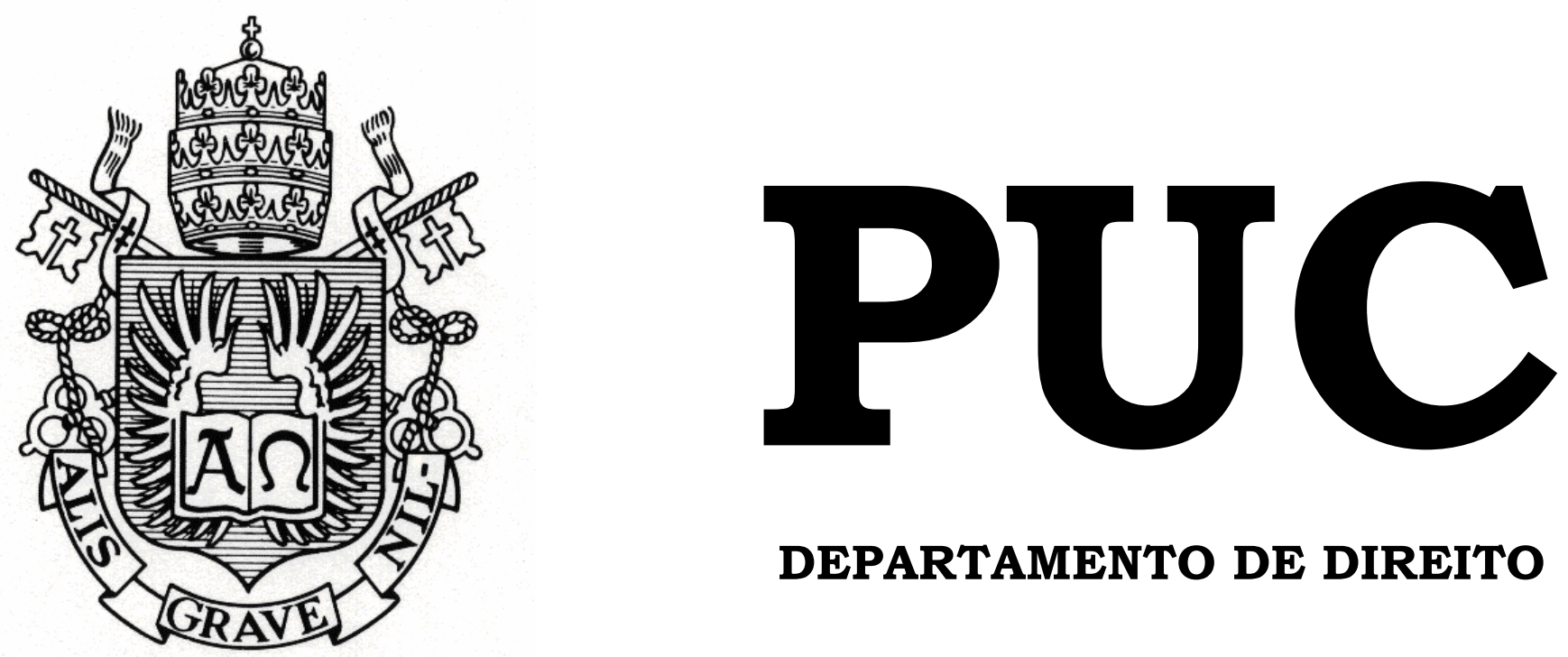

DEPARTAMENTO DE DIREITO

\title{
A PONDERAÇÃO DE INTERESSES NA CONSTITUIÇÃO FEDERAL BRASILEIRA
}

por

BRUNO GOMIERO

ORIENTADOR: FÁBIO CARVALHO LEITE

2005.1

PONTIFÍCIA UNIVERSIDADE CATÓLICA DO RIO DE JANEIRO

RUA MARQUÊS DE SÃO VICENTE, 225 - CEP 22453-900

RIO DE JANEIRO - BRASIL 


\title{
A PONDERAÇÃO DE INTERESSES NA CONSTITUIÇÃO FEDERAL BRASILEIRA
}

\author{
por \\ BRUNO GOMIERO
}

Monografia

apresentada

ao

Departamento de Direito da Pontificia Universidade Católica do Rio de Janeiro (PUC-Rio) para a obtenção do Título de Bacharel em Direito.

Orientador: FÁBIO CARVALHO LEITE 
Este trabalho é dedicado:

Aos meus avós, Antônio, Guido e Encarnação - todos, in memoriam onde estiverem, felizes por mim.

À minha avó

Valdete, sempre ensinando o amor.

Aos meus pais, pelo apoio e confiança de sempre.

Ao meu irmão, pelas grandes lições de vida. 
Meus agradecimentos sinceros:

Aos meus professores da PUC/RJ, mestres, por caminhar de mãos dadas e plantar a semente da curiosidade Em especial ao professor Fábio Carvalho Leite pela atenção dedicada e por magistrais lições

Aos meus amigos, pela infinita compreensão e suporte. 


\section{RESUMO}

Encontramos, diversas vezes, normas que apontam para lados opostos, criando embates normativos. Nosso ordenamento oferece critérios para resolução desses conflitos normativos - a especialidade, a hierarquia e a cronologia. No entanto, devido à Supremacia Constitucional e à Unidade da Constituição, esses critérios clássicos mostram-se insuficientes para solucionar tal problema perante a Lei Maior de nosso país. Contudo, não pode existir em nossa sociedade um conflito sem uma prestação jurisdicional do Estado que componha a lide entre os interessados. Dessa forma, a técnica da Ponderação de Interesses na Constituição Federal Brasileira surge como um instrumento de suma importância, uma vez que se trata de um método de harmonização das lides na interpretação Constitucional. No decorrer do trabalho busca-se demonstrar a funcionalidade, a aplicabilidade e demais pontos principais do método da ponderação. O presente trabalho possui por escopo desenvolver um tema que há muito tem sido discutido, mas que apenas recentemente recebe a devida atenção em nosso ordenamento jurídico. 


\section{SUMÁRIO}

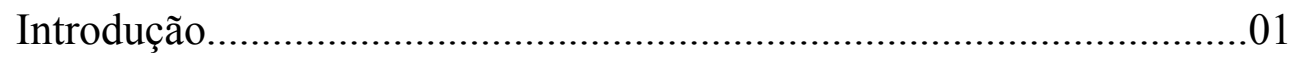

Capitulo I - DO ORDENAMENTO, NORMAS E CONFLITOS

1. Ordenamento e Sistema Jurídico...........................................................03

2. Normas-Regra e Normas-Princípio: diferenças....................................08

3. Critérios Clássicos de Solução de Conflitos........................................15

Capítulo II - CARACTERÍSTICAS DA CONSTITUIÇÃO

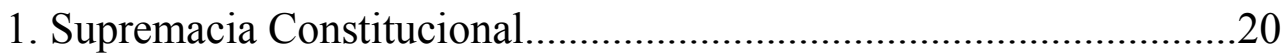

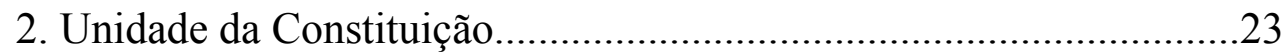

3. Interpretação Conforme a Constituição.................................................25

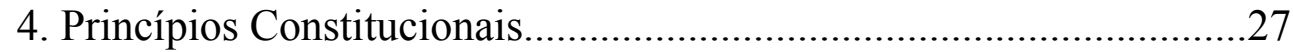

4.1. Proporcionalidade (adequação, necessidade e proporcionalidade

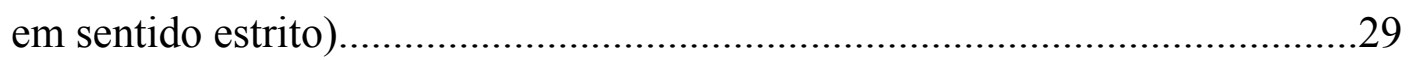

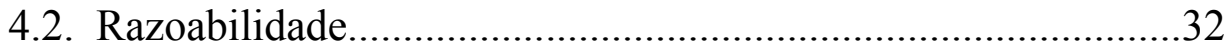

Capítulo III - DA PONDERAÇÃO

1. A Técnica da Ponderação de Interesses...............................................35

1.1. Ponderação e Normas..................................................................41

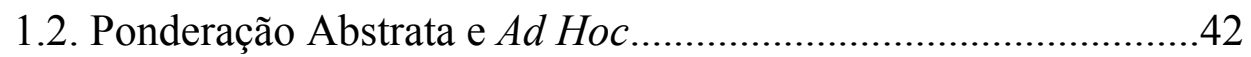

1.3. Fundamentação - Exposição de Motivos -.....................................43

2. O Princípio da Dignidade Humana e Ponderação.................................45

Capítulo IV - CRÍTICAS E EXEMPLOS

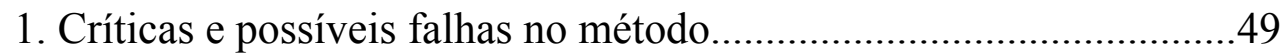

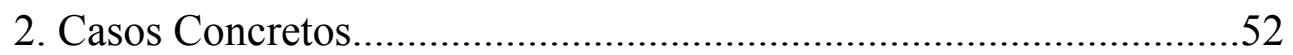

Capítulo V - CONCLUSÃO

Conclusão. .59 


\section{INTRODUÇÃO}

Com uma sociedade em constante mutação devido às grandes evoluções do homem, o direito deve prestar-se a realizar uma adaptação aos tempos modernos, integrando em seu ordenamento os novos conceitos e concepções sociais. Assim, com essa adaptação, podem surgir conflitos entre as normas que compõem tal ordenamento.

Diante disso, o objetivo deste trabalho é estudar uma forma de composição de conflitos aparentes de normas no âmbito constitucional, buscando harmonizar da melhor maneira possível a real vontade da Lei com sua aplicação efetiva na sociedade contemporânea.

Para tanto, inicia com a exposição de algumas noções e conceitos de institutos do Direito, que há muito são alvos de textos e discussões jurídicas.

Norteando o caminho a ser seguido, demonstra a diferença entre Ordenamento e Sistema jurídicos, bem como Regras e Princípios.

Passo seguinte, analisa os critérios clássicos de solução de conflitos de normas, demonstrando sua insuficiência em se tratando de solucionar um aparente conflito de normas constitucionais.

Realiza uma avaliação sobre o princípio da Supremacia Constitucional, bem como o da Unidade da Constituição, mostrando uma interação e sistematização com o princípio da Proporcionalidade e sua forma de incidência, considerando critérios como a adequação, necessidade e a ponderação.

Após essas primeiras noções, entra na Técnica da Ponderação de Interesses propriamente dita, passando por considerações como a interação entre Ponderação e as Normas, a Ponderação Abstrata e $A d H o c$ e a Ponderação e sua fundamentação.

Continuando o raciocínio, apresenta as críticas feitas ao método da Ponderação de interesses e suas possíveis falhas em uma aplicação fática, 
ilustrando com alguns casos que foram resolvidos por meio da técnica em estudo.

Após a exposição teórica, faz uma breve conclusão elucidando o tema e sua importância em nosso ordenamento, trazendo diversos aspectos ligados à sociedade como originária e destinatária direta do Direito.

Cabe ressaltar, por fim, que o presente trabalho em momento algum possui a pretensão de esgotar o tema proposto, mas tão somente realizar uma análise acadêmica, com o escopo principal de estimular uma discussão jurídica acerca de um tema de tamanha importância e relevância social. 


\section{CAPÍTULO I - DO ORDENAMENTO, NORMAS E CONFLITOS}

\section{ORDENAMENTO E SISTEMA JURÍDICO}

O Direito, observada a máxima "Ubi Societas, Ibi Jus" (onde está a sociedade, está o direito), pode ser considerado como um fenômeno social que envolve três aspectos básicos, quais sejam: normativo (ordenamento e ciência do Direito), fático (efetividade social) e axiológico (valor de justiça) ${ }^{1}$. A interação desses aspectos forma uma unidade que atribui dinamicidade ao Direito, uma vez que este deve buscar corresponder às estruturas sociais contemporâneas. Para cumprir tal função, o Direito utiliza modelos normativos, regras e princípios que formam seu alicerce, compondo um “ordenamento jurídico".

A palavra "ordenamento" pode ser aplicada de muitas formas e ter significações das mais variadas. Em seu sentido jurídico, se entende como "dispor em ordem", "arranjar de forma organizada", cuidando para que o sistema de leis seja o mais completo possível, fornecendo recursos não positivados, tais como os princípios gerais de direito, o costume e analogia. Dessa maneira, o "ordenamento jurídico" complementa o conjunto de leis determinado como "sistema".

"Sistema", sob o enfoque jurídico, pode ser entendido como um conjunto de elementos, um complexo de regras, entre os quais se possa encontrar ou definir alguma relação. Tal "sistema" age como uma fonte primária, de onde o aplicador do Direito extrai as primeiras noções acerca da "vontade" da lei e seu cabimento na sociedade. Nessa linha, cabe ressaltar que o intérprete deve se preocupar com a estrutura formal do ordenamento jurídico, pois realizar uma avaliação de uma norma singular perante o ordenamento possibilita determinar de pronto sua validade ou invalidade. 
Segundo o professor Miguel Reale ordenamento jurídico pode ser visto como um macromodelo, cujo âmbito de validade é traçado em razão do modelo constitucional, ao qual devem imperativamente se adequar todos os modelos jurídicos. ${ }^{2}$

Explica o autor que o ordenamento jurídico não deve ser compreendido restritivamente como um mero sistema de leis, mas deve ser percebido como um conjunto de funções, um sistema de normas em sua completa realização, envolvendo as fontes de direito e todos os seus desdobramentos, respeitando a norma constitucional e objetivando a supressão de possíveis lacunas. Assim, seria possível encontrar no sistema jurídico conceitos abstratos como: "competência", "tipicidade", dentre outros, sem que ficassem comprometidos seus entendimentos, pois o intérprete deve realizar uma avaliação com base no ordenamento como um todo.

Norberto Bobbio também entende que o ordenamento jurídico deve ser considerado como objeto autônomo de estudo, não devendo ser confundido com um conjunto de normas. $\mathrm{O}$ autor dispõe em sua obra:

“(...) o Direito não é norma, mas um conjunto coordenado de normas, sendo evidente que uma norma jurídica não se encontra jamais só, mas está ligada a outras normas com as quais forma um sistema normativo". 3

“Entendemos por 'sistema' uma totalidade ordenada, um conjunto de entes entre os quais existe uma certa ordem (...) Quando nos perguntamos se um ordenamento jurídico constitui um sistema, nos perguntamos se as normas que o compõem estão num relacionamento de coerência entre si, e em que condições é possível essa relação". 4

Em sua obra, Bobbio explica que a norma pode ser considerada como a menor unidade em que é possível dividir o ordenamento jurídico, cabendo ao intérprete, entretanto, integrá-la num sistema. Esclarece ainda que não bastaria observar uma diversidade de normas para formar um ordenamento, pois seria

\footnotetext{
${ }^{1}$ REALE, Miguel. Lições Preliminares de Direito. 24 ed. Saraiva, SP, 1998, p.64.

${ }^{2}$ Ibid. p., 197.

${ }^{3}$ BOBBIO, Norberto. Teoria do Ordenamento Jurídico. 5 ed. Univ. de Brasília, BSB, 1994. p.21.
} 
necessário também possuir uma coerência e uma certa ordem entre tais normas.

A doutrina concorda que o ordenamento jurídico engloba, dentre outros, o conceito de sistema, onde este é parte integrante e complementar daquele. Observa ainda que para obter uma "ordem", os entes constituintes não podem estar somente relacionados com o todo que compõem, mas também devem compor uma harmonia entre si.

Em sua análise acerca do tema, Hans Kelsen distingue sistema em dois tipos diferentes: estático e dinâmico. Explica o autor que, no sistema estático, as normas derivam de uma única ou algumas distintas normas originárias e de conteúdo genérico. Dessa forma, as normas derivadas e de conteúdo específico seriam conexas pelo seu conteúdo e objetivo. Já no sistema dinâmico, as normas estão conexas apenas por sua forma de concepção, ou seja, como todas as normas emanam de uma única autoridade ou por delegação direta dessa autoridade, estariam em uma conexão formal. ${ }^{5}$

Kelsen considera o sistema jurídico como um sistema dinâmico, pois o jusfilósofo afirma a validade do sistema de leis pelo fato destas derivarem de uma mesma fonte (teoria da construção escalonada do ordenamento jurídico). ${ }^{6}$

Bobbio critica tal afirmativa ressaltando que, se dessa forma fosse, duas leis com conteúdos absolutamente opostos poderiam estar em perfeita validade dentro de um mesmo sistema, pois somente seria avaliada sua validade formal e nunca a material. Dessa maneira, conclui que sistema jurídico não é dedutivo, mas que deve ser interpretado em um sentido negativo, ou seja, impondo uma ordem lógica que exclui qualquer incompatibilidade. Com essa linha de raciocínio, observa-se que as normas de um sistema não necessitam de uma

\footnotetext{
${ }^{4}$ Ibid, p.71.

${ }^{5}$ BOBBIO, Norberto. O Positivismo Jurídico - Lições de Filosofia do Direito. Ícone editora, SP, 1995, p., 199-202.

${ }^{6}$ Ibid, p., 199.
} 
correlação entre si, podendo dispor de assuntos absolutamente diversos, desde que não venham a ser contraditórias. ${ }^{7}$

Outro ponto que deve ser discutido trata da unidade do ordenamento. Uma vez que as normas possuem certo grau de hierarquia entre si, como seria possível falar em unidade?

Segundo as lições de Bobbio, devido à constante necessidade de novas normas para regular novas condutas sociais, os ordenamentos jurídicos possuem fontes reconhecidas - normas já criadas e simplesmente incorporadas ao ordenamento - e fontes delegadas - normas produzidas por quem de direito ou por sua delegação direta. Assim, o ordenamento jurídico pode ser entendido como um ordenamento complexo, onde as normas inferiores são mais numerosas, mais específicas e possuem uma relação de dependência com as superiores, ao passo que as superiores são normas mais genéricas, menos numerosas e delas derivam as inferiores, até alcançar uma norma fundamental, que então, diante da estrutura hierárquica apresentada, confere unidade ao ordenamento.

Uma vez analisados os dois elementos básicos presentes em um ordenamento jurídico - a unidade e a coerência - resta estudar sua completude e suas possíveis lacunas.

Atualmente, o ordenamento jurídico se encontra em permanente interconexão e intercâmbio com a sociedade, logo, se apresenta como um sistema aberto, pois se sujeita a uma constante influência de forças externas. Tal característica é inerente ao ordenamento jurídico, pois sem a influência das relações sociais este somente existiria em sua forma, mas não cumpriria sua função precípua.

Dessa maneira, para um ordenamento jurídico alcançar sua proposição principal de regulador social, deve possuir normas diversas, de modo que este seja passível de adaptação e mesmo assim transmita uma segurança jurídica

\footnotetext{
${ }^{7}$ Ibid, p., 200.
} 
para as relações sociais. Assim, um ordenamento jurídico, além dos elementos já mencionados, também deve possuir uma completude, ou seja, a propriedade de regular qualquer caso ou problema que confrontar. Para tanto, o intérprete deve valer-se das normas positivadas e de todos os recursos encontrados no próprio ordenamento.

Para elucidar o tema vale a lição de Savigny:

“... o conjunto das fontes de direito... forma um todo, que está destinado à solução de todas as questões surgidas no campo do Direito. Para corresponder a tal finalidade, ele deve apresentar estas características: unidade e completude... O procedimento ordinário consiste em tirar do conjunto das fontes um sistema de direito... Falta a unidade, e então trata-se de remover uma contradição; falta a completude, e então trata-se de preencher uma lacuna. Na realidade, porém, essas duas coisas podem reduzir-se a um único conceito fundamental. De fato, o que tentamos estabelecer é sempre a unidade: a unidade negativa, com a eliminação das contradições; a unidade positiva, com o preenchimento das lacunas." 8

Savigny nos mostra que o Direito possui a função de dirimir os conflitos sociais, uma vez que a soma de suas fontes forma um "todo", onde estariam presentes as maneiras de composição das questões surgidas na sociedade. $\mathrm{O}$ autor entende que a característica de completude do ordenamento é intrínseca à característica da unidade, definindo como "unidade negativa" a busca pelo intérprete de eliminar possíveis contradições entre as normas e "unidade positiva", o preenchimento das lacunas do ordenamento, ou seja, a busca de uma completude. Não acompanhado, entretanto, por Bobbio, que considera a unidade e a completude como características autônomas, passíveis de um estudo separado.

O elemento da completude do ordenamento jurídico, aplicado ao caso concreto, fornece à sociedade uma "garantia de solução", pois através dessa característica o Estado está obrigado a conceder uma prestação jurisdicional sempre que provocado, não podendo o juiz se escusar de julgar determinado

\footnotetext{
${ }^{8}$ Apud, BOBBIO, Op. cit., p. 116.
} 
fato alegando a inexistência de uma norma, ou ainda, julgar a lide com elementos estranhos ao ordenamento.

Para que tal característica alcance sua finalidade, o próprio ordenamento jurídico fornece elementos que servem de base para realizar sua completude, evitando uma possível ausência de prestação jurisdicional por parte do Estado. Como exemplo prático cabe citar o artigo $4^{\circ}$ da Lei de Introdução ao Código Civil', dispondo in verbis: "Art. $4^{\circ}$ Quando a lei for omissa, o juiz decidirá o caso de acordo com a analogia, os costumes e os principios gerais de direito".

Passo seguinte, continuando uma linha de raciocínio traçada com o objetivo de chegar ao aparente conflito de princípios na Constituição Federal, cabe tratar das diferenças entre as regras e os princípios.

\section{NORMAS-REGRA E NORMAS-PRINCÍPIO: DIFERENÇAS}

Determinar um conceito de regras e princípios auxilia o intérprete a compreender as formas de solução de conflitos entre essas espécies normativas. Cabe salientar que a doutrina majoritária possui um posicionamento assemelhado sobre o tema, discrepando apenas em nuanças, destacando-se, entretanto, o posicionamento do professor Humberto Ávila em sua obra, "Teoria dos princípios", que trata o tema com um enfoque crítico aos conceitos de regras e princípios, bem como suas relações com o ordenamento jurídico $^{10}$.

\footnotetext{
${ }^{9}$ Destaque-se que tal exemplo é referente ao ordenamento jurídico brasileiro.

${ }^{10}$ ÁVILA, Humberto. Teoria dos Princípios. 04 ed. Malheiros, SP, 2004. O professor Humberto Ávila traz em sua obra uma visão crítica acerca do tema que se encontra pacificado na doutrina. Busca revitalizar o estudo e a forma de pensar sobre uma matéria que, cada vez mais, recebe tamanha importância. Analisa os conceitos pré-moldados pela doutrina, criando um posicionamento destacado, conferindo um enfoque crítico aos conceitos de regras e princípios. Na estrutura de aplicação das
} 
Destarte, uma distinção básica deve ser realizada para melhor entendimento do tema. A norma jurídica consiste no sentido que se pode extrair a partir da interpretação sistemática dos textos normativos ${ }^{11}$, um juízo axiológico do intérprete, sendo a norma um gênero normativo abstrato do qual as regras e os princípios são espécies derivadas. Dessa forma, na composição de sistemas e ordenamentos jurídicos verificam-se as normas-regra e as normas-princípio.

Conforme J. J. Gomes Canotilho, em seu entendimento recente ${ }^{12}$, a norma se distingue do princípio por conter uma regra, divergindo de José Afonso da Silva, que afirma serem as normas preceitos que tutelam situações subjetivas de vantagem ou de vínculo, não necessitando a percepção de uma regra para sua distinção quanto aos princípios ${ }^{13}$.

Ante a primeira noção de diferenciação entre gênero e espécie, que forma a base de composição de um ordenamento jurídico, é necessária a exposição de alguns conceitos atribuídos pela doutrina para compreender a relação das normas com o ordenamento jurídico que compõem.

Grande parte da doutrina busca critérios clássicos de diferenciação das normas no ordenamento, tais como: a necessidade de observar atribuições específicas para uma conceituação prática e a exaltação dos princípios em detrimento às regras. A exposição de alguns conceitos atribuídos pela doutrina facilita compreender a decorrente relação das normas com o ordenamento jurídico que compõem.

Ronald Dworkin, em sua obra Los Derechos en Serio, escreve:

normas (gênero), Humberto Ávila classifica os postulados normativos como metanormas que orientam o correto cabimento das regras e princípios (espécies).

${ }^{11}$ ÁVILA, Humberto. Op. cit. p., 22.

${ }^{12}$ Note-se que J. J. Gomes Canotilho realiza a distinção entre regras e princípios como espécies de normas em sua obra Direito Constitucional, p. 172, porém, em sua obra Fundamentos da Constituição, p. 49, editada pouco tempo após, porém, no mesmo ano da primeira, aponta apenas para normas e princípios, sendo a "regra" considerada um parâmetro de diferenciação.

${ }^{13}$ SILVA, José Afonso. Curso de Direito Constitucional Positivo. 19 ed. Malheiros, SP, 2001, p. 95. 
"Llamo $<$ directriz $>$ o < directriz política $>$ al tipo de estándar que propone un objetivo que ha de ser alcanzado; (...) Llamo <principio> a un estándar que ha de ser observado, no porque favorezca o asegure una situación económica, política o social que se considera deseable, sino porque es una exigencia de la justicia, la equidad o alguna outra dimensión de la moralidad". 14

"La diferencia entre principios jurídicos y normas jurídicas es una distinción lógica. Ambos conjuntos de estándares apuntan a decisiones particulares referentes a la obligación jurídica en determinadas circunstancias, pero difieren em el carácter de la orientación que dan. Las normas son aplicables a la manera de disyuntivas. Si los hechos que estipula una norma están dados, entonces o bien la norma es válida, em cuyo caso la respuesta que da debe ser aceptada, o bien no lo es, y entonces no aporta nada a la decisión". ${ }^{15}$

Dworkin, admitindo os conceitos de normas e princípios, realiza uma distinção lógica entre estes, referindo-se ao caráter diferenciador de orientação que conferem à decisão. $\mathrm{O}$ autor ensina que, havendo uma adequação do preceito da norma ao fato concreto esta deve ser aplicada totalmente, porém, caso tal harmonia não seja observada, a norma em nada contribui para a decisão. Assim, Dworkin compõe a tese do "se, então", onde as normas seriam aplicadas pelo "tudo ou nada". Com relação aos princípios, o autor entende que a aplicação destes ocorre por uma gradação, ou seja, por possuírem uma dimensão de "peso", podem ser aplicados ou não, dependendo apenas da análise que receberão frente ao caso concreto.

O professor Manuel Messias Peixinho, também admitindo os conceitos de normas e princípios e seguindo as lições de J. J. Gomes Canotilho, encontra-se na mesma linha de entendimento de Dworkin, considerando que um critério de diferenciação é a determinabilidade de aplicação, ou seja, as normas podem ser aplicadas de maneira direta, pois possuem uma forma

\footnotetext{
${ }^{14}$ DWORKIN, Ronald. Los Derechos en Serio. 2 ed. Ariel, Espanha, 1995. p., 72.

${ }^{15}$ Ibid. p., 74.
} 
concreta, ao passo que os princípios necessitam de uma concretização para sua aplicação $^{16}$.

Ao seu turno, Humberto Ávila entende que o critério "hipotéticocondicional", 17 que dispõe serem as regras aplicadas de modo "se, então", não pode ser observado como critério de distinção. A crítica do autor refere-se à imprecisão de tal critério e sua relativização, pois a existência de uma hipótese depende do modo de sua interpretação. Assim, pelo modo "se, então", o objeto da interpretação seria considerado mais válido que seu resultado prático. Quanto ao critério do "modo final de aplicação", onde as regras seriam aplicadas pelo "tudo ou nada" (Dworkin) e os princípios por uma gradação, a crítica parte da assertiva de que o modo de aplicação não pode ser determinado pelo dispositivo objeto da interpretação em si, mas sim em função das conexões axiológicas atribuídas pelo intérprete. Outro ponto de fundamentação ressalta que a conseqüência estabelecida pela norma é variante, uma vez que encontra vinculada sua aplicação às razões substanciais consideradas pelo aplicador no caso concreto.

Diante disso, Humberto Ávila propõe como primeiro critério de dissociação a "medida de contribuição para a decisão", através do qual verifica-se que as regras são normas preliminarmente decisivas e abarcantes, pois possuem uma pretensão terminativa, buscando abranger todos os aspectos relevantes para a tomada da decisão, ao mesmo tempo em que realizam o preenchimento das condições de aplicabilidade. Já os princípios mostram-se normas complementares e parciais, pois abrangem parte dos aspectos relevantes para uma tomada de decisão, sem, contudo, pretender gerar uma solução específica.

\footnotetext{
${ }^{16}$ PEIXINHO, Manuel Messias, A Interpretação da Constituição e os Princípios Fundamentais Elementos para uma Hermenêutica Constitucional, 2 ed., Lumen Júris, Rio de Janeiro, 2000, p. 107.

${ }^{17}$ ÁVILA, Humberto. Op. cit., p., 31.

${ }^{18}$ Ibid, p. 35.

${ }^{19}$ Ibid., p.68.
} 
Uma segunda característica que Dworkin ressalta refere-se ao caráter de "peso de importância" que possuem os princípios, sendo essa atribuição exclusiva desse tipo de norma.

Assim, outra forma de diferenciação entre normas e princípios seria pela forma como incidem no caso de uma antinomia, dispondo que, se há conflito entre princípios, o intérprete deve realizar uma ponderação, sobressaindo o de maior valor social para o caso concreto, sem, contudo, invalidar o princípio de menor cabimento no caso. Já se o conflito ocorre entre normas, uma delas deve, obrigatoriamente, ser descartada por inválida e encontrar-se incompatível com o ordenamento.

Dispõe o autor em sua obra:

"Los princípios tienen una dimensión que falta en las normas: la dimensión del peso o importancia. Cuando los principios se interfieren (...), quien debe resolver el conflicto tiene que tener en cuenta el peso relativo de cada uno. (...) Las normas no tienen esta dimensión. Al hablar de reglas o normas, podemos decir que son o que no son 'funcionalmente' importantes (...) Si se da um conflicto entre normas, uma de ellas no puede ser valida". ${ }^{20}$

Manuel Messias Peixinho, em congruência com Dworkin, acompanhando também J. J. Gomes Canotilho, confere aos princípios um prevalecente grau de abstração, uma vez que, realizando uma análise de "conteúdo de informação",21, separa os princípios abertos de normas com disciplina jurídica imediata, realizando uma separação qualitativa, quanto à estrutura lógica e também intencional da norma.

Humberto Ávila, em posição contrária aos doutrinadores estudados, observa que o critério do "conflito normativo",22, distinguindo princípios e regras pela forma como são solucionados seus conflitos, não deve prosperar. Afirma que a ponderação não é um método privativo dos princípios, sendo as

\footnotetext{
${ }^{20}$ DWORKIN, Ronald. Op. cit., p. 77.

${ }^{21}$ PEIXINHO, Manuel Messias. Op. cit., p. 107.

${ }^{22}$ ÁVILA, Humberto. Op. cit., p. 42.
} 
regras também merecedoras de tal avaliação. Cita a ocorrência de casos onde o próprio ordenamento jurídico permite ao intérprete a ponderação de uma regra (estado de necessidade versus uma multa de trânsito por excesso de velocidade, por ex.). Em adição, considera errado afirmar que os princípios "possuem" uma dimensão de peso, considerando que esta incide sobre as razões e os fins aos quais os princípios se destinam ${ }^{23}$.

Apresenta em sua crítica o critério da "natureza do comportamento prescrito ${ }^{24}$, dissociando os princípios e as regras pelo modo como prescrevem o comportamento, considerando as regras como normas de descrição imediata, pois estabelecem obrigações, permissões e proibições por meio de condutas a serem observadas. Ao passo que os princípios seriam normas imediatamente finalísticas, pois atribuem um estado para as coisas, de maneira que para sua realização se faz necessária a observação de determinados comportamentos. Assim, as regras prevêem um comportamento e os princípios um fim, entrando em relação recíproca de existência.

Por fim, apresenta o autor o critério da "natureza da justificação exigida, ${ }^{25}$, ou seja, tanto as normas-regra quanto as normas-princípio exigem para sua aplicação determinada justificação, onde as regras, por possuírem um caráter descritivo maior, demandam a observação de uma relação entre o fato, a norma-regra e a finalidade desta. Ao seu turno, os princípios, por possuírem um caráter finalístico, exigem uma correlação entre os efeitos da conduta que deve ser observada para alcançar o fim colimado pela regra e a realização gradual do estado de coisas exigido. Para uma compreensão mais apurada, cabe citar como exemplo a interpretação do princípio da moralidade, onde se encontra a motivação, a lealdade e a seriedade compondo o estado das coisas, ao lado da necessidade de se observar comportamentos esclarecedores, leais e sérios, que não são indicados ou definidos pelo princípio. Em decorrência

\footnotetext{
${ }^{23}$ Ibid, p. 44.

${ }^{24}$ Ibid, p. 63.
} 
disso, surge outra característica de dissociação, pois é possível afirmar que as regras assumem um caráter primariamente retrospectivo e os princípios um caráter primariamente prospectivo.

Depois de realizar as diferenciações, resta expor seus conceitos sobre o tema, quais sejam estes:

\begin{abstract}
“As regras são normas imediatamente descritivas, primariamente retrospectivas e com pretensão de decidibilidade e abrangência, para cuja aplicação se exige a avaliação da correspondência, sempre centrada na finalidade que lhes dá suporte ou nos principios que lhes são axiológicamente sobrejacentes, entre a construção conceitual da descrição normativa e a construção conceitual dos fatos. Os princípios são normas imediatamente finalísticas, primariamente prospectivas e com pretensão de complementaridade e de parcialidade, para cuja aplicação se demanda uma avaliação da correlação entre o estado de coisas a ser promovido e os efeitos decorrentes da conduta havida como necessária à sua promoção" ${ }^{26}$
\end{abstract}

Diante do exposto, verifica-se que um modelo de sistema normativo composto apenas por princípios proporcionaria uma grande adaptabilidade do sistema jurídico aos fatos sociais que lhe fossem impostos, permitindo realizar uma avaliação permanente entre os mais diversos valores sociais aplicados ao Direito. Porém, se desta forma fosse, verificaria-se um sistema absolutamente abstrato, instável e inconstante, pois sempre ficaria vinculado ao entendimento subjetivo do intérprete.

Ao seu turno, um modelo de sistema normativo composto apenas por regras proporcionaria uma adaptabilidade mínima do sistema jurídico aos fatos sociais que lhe fossem impostos, ocorrendo uma redução fatídica do Direito, pois o intérprete ficaria restringido de realizar qualquer avaliação de valor, conferindo ao ordenamento uma grande chance de nunca alcançar a completude.

\footnotetext{
${ }^{25}$ Ibid, p. 65 .

${ }^{26}$ Ibid, p. 70.
} 
Assim, um ordenamento jurídico composto por normas-regra e normasprincípio mostra-se mais eficiente perante a sociedade, possibilitando ao intérprete encontrar coerência, unidade e a completude necessárias por realizar uma adequada aplicação aos casos concretos.

Após estudar os princípios e as regras, cabe passar ao próximo ponto, onde serão observados os critérios comumente adotados para a solução de conflitos dentro do ordenamento.

\section{CRITÉRIOS CLÁSSICOS DE SOLUÇÃO DE CONFLITOS}

No Direito Positivado, o sistema de leis torna-se fundamental para a composição de uma lide. Porém, por mais zeloso e diligente que seja o legislador ao cumprir sua função primária, é de se considerar quase impossível que não haja lacuna (falta de unidade - unidade negativa) ou contradição (falta de completude - unidade positiva) em sua obra legislativa.

Como já observado em ponto anterior, o ordenamento jurídico deve possuir unidade, coerência e completude. Porém, devido à grande demanda por novos regulamentos comportamentais, face ao desdobramento natural das relações sociais, muitas leis surgem a todo instante, ocasionando diversos fenômenos que devem ser analisados, pois, como bem aponta Maria Helena Diniz, a questão do conflito normativo é, eminentemente, sistemática. ${ }^{27}$

A antinomia, ou de forma mais simples, o conflito entre duas leis, pode ser classificada de várias maneiras, bastando verificar sua incidência. Conforme Maria Helena Diniz, a antinomia representa o conflito entre duas

\footnotetext{
${ }^{27}$ DINIZ, Maria Helena. Conflito de Normas. 03 ed. Saraiva, SP, 1998, p. 07.
} 
normas, entre dois princípios ou entre uma norma e um princípio geral de direito em sua aplicação prática a um caso particular. ${ }^{28}$

Os critérios usados para a solução das antinomias são critérios normativos, de modo que no próprio ordenamento jurídico o intérprete os encontra, buscando alcançar sua coerência e completude. Os três critérios clássicos de solução utilizados - o hierárquico, o cronológico e da especialidade - são o enfoque deste ponto.

O critério hierárquico, "lex superior derogat legi inferioi", é baseado no fato de que as fontes produtoras das normas estão em posição escalonada, atribuindo uma hierarquia entre elas. Como observado por Hans Kelsen, em sua teoria da construção escalonada do ordenamento jurídico, as normas encontram-se ordenadas de forma piramidal, onde a base é formada por leis emanadas de um poder cada vez mais derivado e menos constituinte, e o ápice da pirâmide é formado pela Constituição, que é a lei emanada diretamente do poder constituinte. Com isso, as normas de nível superior devem prevalecer sobre as normas de nível inferior.

Afastada a hierarquia normativa, o critério da especialidade, "lex specialis derogat legi generali”, utiliza-se da maneira como é tratado o assunto pela norma em questionamento, para então classificá-la em especial ou geral. Como observado em ponto anterior, as normas derivadas podem alcançar uma abordagem cada vez mais específica do assunto a que se referem. Dessa forma, se uma lei contiver em seu texto todos os elementos de uma lei geral e mais alguns elementos singulares sobre a matéria ora tratada será tida como especial. Assim, a lei geral delimita a matéria tratada formando uma base para a construção de uma lei especial, que, por ser mais específica, prevalece sobre a lei geral.

O terceiro critério de solução de antinomias, o cronológico, "lex posterior derogat legi priori", surge para solucionar os conflitos das normas

\footnotetext{
${ }^{28}$ Ibid, p. 15.
} 
que se encontram no mesmo escalão hierárquico, fazendo prevalecer a mais recente, ou seja, se duas normas são hierarquicamente equivalentes, porém contraditórias, a validade da norma editada recentemente sobreleva a da norma anterior, pois a norma posterior teria maior adequação com a realidade social. É facultado ao legislador, comparando as relações sociais contemporâneas com a necessidade de orientação de nova conduta, revogar lei anterior por meio de uma lei nova que seja incompatível com aquela. Cabe ressaltar que tal critério deve ser interpretado de maneira parcial, pois sua aplicação pode variar em relação ao contexto no qual é inserido, restando quatro possibilidades básicas para o intérprete, podendo ser demonstrado in verbis, conforme afirma Maria Helena Diniz ${ }^{29}$ :

(1) se a incoerência entre as normas ocorrer de forma total-total, o princípio deverá ser observado;

(2) se tal incompatibilidade ocorrer de forma total-parcial, onde a lei contradita parcialmente seja uma lei especial, o princípio pode vir a ser afastado e as duas leis seriam válidas;

(3) se a contradição ocorrer entre uma lei especial anterior e uma lei geral posterior, o princípio pode vir a ser afastado e ambas as leis teriam suas validades mantidas;

(4) se incidir de forma parcial-parcial, a lei posterior poderá afastar a lei anterior, porém, em alguns casos, somente invalidará a lei anterior se esse foi o intuito do legislador, que deve ser expresso.

O critério cronológico está disposto no artigo $2^{\circ}, \S 1^{\circ}$, da Lei de Introdução ao Código $\mathrm{Civi}^{30}$, sendo:

“Art. $2^{\circ}$ Não se destinando à vigência temporária, a lei terá vigor até que outra a modifique ou revogue.

\footnotetext{
${ }^{29}$ Ibid, p., 35 .

${ }^{30}$ Note-se que o exemplo refere-se ao ordenamento jurídico pátrio.
} 
$\S 1^{\circ}$ A lei posterior revoga a anterior quando expressamente o declare, quando seja com ela incompativel ou quando regule inteiramente a matéria de que tratava a anterior."

Outra questão observada, para solucionar alguns casos concretos, é a necessidade do intérprete de relacionar os critérios, pois comumente cabe a aplicação de dois ou mais deles na tentativa de desfazer um conflito. Não seria grande problema se, no cabimento de dois ou mais critérios, ambos indicassem para a mesma solução. Porém, em determinadas situações ocorre uma diversidade no direcionamento do intérprete ao analisar os critérios, recebendo estas antinomias a denominação de segundo grau. Dessa maneira, cabe uma análise entre as possíveis incidências de conflitos e suas soluções.

Diante do embate entre o critério hierárquico e o cronológico, há uma valoração maior para a superioridade hierárquica, pois não seria admissível que uma lei inferior revogasse uma lei superior, mesmo que posterior a esta, sob pena de violação dos princípios norteadores básicos como o da ordem hierárquica e o da segurança jurídica.

No conflito entre a especialidade e a cronologia, verifica-se uma prevalência do critério da especialidade, surgindo a regra: "Lex posterior generalis non derogat priori speciali”.

No terceiro conflito, estuda-se a relação decorrente do entrelace dos critérios da hierarquia e da especialidade, onde não há uma regra para pronunciar qual critério deve prevalecer, tornando de suma importância o papel do intérprete, que deve agir com razoabilidade em sua escolha. A doutrina considera, ao menos teoricamente, a predominância do critério hierárquico, principalmente se o embate ocorrer entre uma norma constitucional e outra infraconstitucional.

Verificados os critérios clássicos de solução de antinomias, percebe-se a fragilidade do sistema jurídico no que concerne a um aparente embate de normas na Lei Maior, pois, se o intérprete enfrentar um conflito entre normas 
inseridas na Constituição - contemporâneas, do mesmo nível e gerais - não encontrará nos critérios clássicos forma de solucionar o problema, ofuscando a noção de justiça do ordenamento.

Contudo, antes de analisar como ocorre e se desenrola tal questão, cabe estudar alguns princípios constitucionais que formam o alicerce para a resolução desse conflito. 


\section{CAPÍTULO II - CARACTERÍSTICAS DA CONSTITUIÇÃO}

\section{SUPREMACIA CONSTITUCIONAL}

A Constituição pode ser compreendida como a expressão da vontade soberana do povo desdobrada em um conjunto de normas que cuidam dos princípios fundamentais do Estado, dos direitos e garantias fundamentais dos indivíduos, da organização dos poderes, da ordem econômica e financeira e da ordem social.

Tratando-se da vontade manifestada do povo, a Constituição é um instrumento criado por este para reger e assegurar as bases da sociedade. Esse "poder" popular para estabelecer uma constituição denomina-se Poder Constituinte. Nos ensinamentos de Bobbio, Poder Constituinte é a fonte das fontes $^{31}$, atribuindo a este o ponto máximo de referência de todas as normas. Conforme Paulo Bonavides, a teoria do poder constituinte é uma teoria de legitimidade do poder $^{32}$, onde o povo é imbuído de legitimidade para constituir uma Lei Suprema.

Por ser uma norma emanada do Poder Constituinte e comportar grande relevância nas matérias que regula, atribuiu-se à Carta Magna uma rigidez formal maior que aquela conferida às demais leis, ou seja, as Constituições rígidas são aquelas que prevêem um procedimento especial e mais dificultoso para a sua alteração, do que para a elaboração ou modificação de uma lei infraconstitucional. De modo que, se a legislação ordinária pudesse alterar o texto constitucional, o aplicador do direito estaria diante de uma Constituição flexível, não verificando hierarquia entre as normas. Por isso também, cabe dizer que a Lei das leis é norma superior em relação às demais

\footnotetext{
${ }^{31}$ BOBBIO, Norberto. Teoria da Norma Jurídica. São Paulo, Bauru, Edipro, 2003, p. 11.
} 
infraconstitucionais e, portanto, a interpretação do sistema jurídico deve ser feita de cima para baixo, visto que a Constituição é norma-origem ${ }^{33}$, não existindo outra acima dela.

Dessa maneira, nota-se de pronto que, para haver uma supremacia constitucional, é necessário que haja uma rigidez e uma subordinação hierárquica perante as demais normas do ordenamento jurídico.

A doutrina mostra-se harmônica a respeito do tema. José Afonso da Silva afirma que a Constituição é rígida ${ }^{34}$, verificando por conseqüência dessa rigidez o princípio da Supremacia Constitucional. Explica ainda estar a Constituição Federal no ápice do ordenamento jurídico conferindo validade a este. Seguindo a mesma linha de entendimento, o professor Meirelles Teixeira, acerca da supremacia constitucional, afirma em sua obra:

"Ela é o ponto de referência máximo, orientador de toda a atividade estatal; nela vão buscar seu fundamento último todos os direitos, garantias $e$ instituições; ela é a fonte, a matriz de todos os ramos do Direito, servindo também de limite a toda atividade normativa, administrativa e jurisdicional do Estado, que, destarte, autolimita-se, isto é, estabelece limites a sua própria atividade, através da Constituição rígida. "3.

Teixeira ensina que, através da Constituição, o Estado encontra fundamento e limitação para todas as suas atividades, conceituando a Lei Maior como "ponto de referência máximo" para todo o Direito, estabelecendo uma supremacia constitucional perante as leis infraconstitucionais e demais atos estatais. A Constituição mostra-se como a base dos institutos que regem a sociedade, uma vez que esta é a Lei Fundamental e Suprema do Estado. Assim, o próprio Estado, seus agentes e autoridades são determinados e estão

\footnotetext{
${ }^{32}$ BONAVIDES, Paulo. Curso de Direito Constitucional. 14 ${ }^{\mathrm{a}}$ ed. Malheiros, SP, 2004, p. 141.

${ }^{33}$ DINIZ, Maria Helena. Op. cit. p. 14.

${ }^{34}$ SILVA, José Afonso da. Op. cit. p. 46. Ressalte-se que o autor faz referência à Constituição Federal de 1988, da República Federativa do Brasil, não atribuindo a característica da rigidez a toda e qualquer Constituição.

35 TEIXEIRA, J.H. Meirelles. Curso de Direito Constitucional. São Paulo: Forense Universitária, 1991, p. 116/ 117.
} 
subordinados à Lei Maior, encontrando-se delineadas suas atribuições e competências. A rigidez constitucional indica, dentre outras características, que há uma limitação aos poderes públicos que não podem agir em desacordo com a norma constitucional.

Ainda sobre a rigidez constitucional e sua relação com o princípio da supremacia constitucional Paulo Bonavides dispõe em seu livro:

"As constituições rígidas, sendo constituições em sentido formal, demandam um processo especial de revisão. Esse processo lhes confere estabilidade ou rigidez bem superior àquela que as leis ordinárias desfrutam. Daqui procede pois a supremacia incontrastável da lei constitucional sobre as demais regras de direito vigente num determinado ordenamento. ${ }^{, 36}$

O autor explica que a supremacia constitucional é proveniente da dificuldade imposta pela rigidez ao processo de modificação do texto da Constituição, que é uma característica exclusiva desta.

Diante disso, verifica-se derivar do princípio da supremacia constitucional o controle de constitucionalidade das leis, uma vez que estas devem obediência às normas implícitas e explícitas da Constituição, devendo ser consideradas como inconstitucionais se violarem tais comandos, restando, portanto, seu banimento do ordenamento jurídico, como expõe Maria Helena Diniz:

"O controle da constitucionalidade significa impedir a subsistência da eficácia da norma contrária à Constituição, pressupondo, necessariamente, a idéia da supremacia constitucional, pois, na existência de um escalonamento normativo, onde é a Constituição a norma-origem, encontra o legislador seu limite, devendo obedecer à forma prevista e ao conteúdo anteposto. Por isso, ato normativo contrário ao texto constitucional será considerado presumidamente constitucional até que por meio de mecanismos previstos constitucionalmente se declare sua inconstitucionalidade e, conseqüentemente, a retirada de sua eficácia, ou executoriedade.,"37

\footnotetext{
${ }^{36}$ BONAVIDES, Paulo. Op. cit. p., 296.

${ }^{37}$ DINIZ, Maria Helena. Op. cit. p., 14.
} 
Cabe ressaltar que, apesar da imutabilidade relativa da Carta Magna, sempre que necessário deverá nela se operar modificação, de acordo com os requisitos formais estabelecidos pela própria Constituição, para que seu texto seja compatibilizado com a dinâmica social, preservando sua legitimidade e a vontade popular.

Ressalte-se que tais modificações não constituem ofensa ao texto da Lei Maior ou ao princípio da supremacia constitucional, pois somente podem ocorrer através dos meios previamente determinados na própria Constituição, devendo respeito aos limites que esta impõe. Como exemplo prático, cabe citar o fenômeno das "cláusulas pétreas" que somente comportam alterações que, segundo José Afonso da Silva, na esteira de Nelson de Souza Sampaio, as ampliem ou melhorem de alguma maneira.

Dessa forma, por ser a expressão da vontade popular, possuir uma rigidez diferenciada e uma posição privilegiada no escalonamento do ordenamento jurídico, sendo-lhe devida aquiescência por todas as normas infraconstitucionais, torna-se justa a atribuição de supremacia, com o intuito de que seja mantida a estabilidade social, as diretivas da Administração Pública e a própria Soberania.

\section{UNIDADE DA CONSTITUIÇÃO}

Como observado em ponto anterior, a supremacia constitucional proporciona para o ordenamento jurídico uma unidade. Entretanto, a supremacia não se desdobra somente perante as normas infraconstitucionais, mas também deve ser aplicada na própria Constituição, ou seja, é na Lei fundamental que repousa a unidade da ordem jurídica e a unidade também se projeta sobre a Constituição. Dessa forma, verifica-se que a unidade confere 
ao ordenamento e à Lei Suprema uma lógica jurídica, proporcionando uma funcionalidade. Assim, as normas da Constituição possuem estreita existência e correlação. Logo, a violação de uma delas pode acarretar um enfraquecimento de sua rigidez, proporcionando uma facilitação para a violação de outras.

O professor Peixinho alude ao tema da unidade dispondo em seu livro:

"Significa que o intérprete deve considerar a Constituição em sua totalidade, procurando harmonizar os lugares de conflitos entre as suas diversas normas. Daí, a perfeita compatibilidade entre o princípio do Estado de Direito com o democrático, do princípio democrático com o socialista, princípio unitário com o da autonomia regional. Este princípio muito se assemelha à interpretação sistemática que busca a coerência do ordenamento jurídico". ${ }^{38}$

Peixinho entende caber ao intérprete constitucional a realização de uma compreensão harmônica das normas dispostas na lei Maior, devendo analisar cada uma como parte integrante de um conjunto maior, sistematizando suas disposições para evitar conflitos. Nesse mesmo entendimento, o professor J. J. Gomes Canotilho explica que a Constituição somente pode ser entendida em sua globalidade, onde o aplicador deve amenizar os espaços de tensão existentes entre as normas constitucionais realizando um entendimento generalizado. Com uma base de entendimento similar, Eduardo Garcia Enterría $^{39}$ considera que a unidade do ordenamento jurídico é representada por uma 'ordem de valores' materiais, disposta pelos princípios gerais de direito, sendo missão do intérprete avaliar e realizar a coesão necessária para alcançar

\footnotetext{
${ }^{38}$ PEIXINHO, Manoel Messias. Op. Cit. p., 86.

${ }^{39}$ O Professor Enterría explica que "La unidad del ordenamiento es, sobre todo, una unidad material de sentido, expresada en unos principios generales del Derecho, que o al intérprete le toca investigar y descubrir (sobre todo, naturalmente, al intérprete judicial, a la jurisprudencia), o la Constitución los ha declarado de manera formal, destacando entre todos, por la decisión suprema de la comunidad que la ha hecho, unos valores sociales determinados que se proclaman en el solemne momento constituyente como primordiales y básicos de toda la vida colectiva". Trecho retirado de sua obra La Constitución como norma y el Tribunal Constitucional, Ed. Civitas, Madrid, 1994, pág. 97, citado em um artigo no Tribunal Boliviano e em ADIN proposta por partidos políticos em Portugal, sendo
} 
a unidade, jamais pairando a unidade sobre regras simplesmente formais de produção de normas.

Assim, nota-se que uma função importante da unidade da constituição é direcionar o intérprete na busca da harmonia entre os dispositivos aparentemente conflitantes da Lei Maior. Ao seu turno, sempre que houver impossibilidade de conciliação plena, o aplicador do direito deve buscar a forma que comporte menor prejuízo para ambas as normas.

Diante do exposto, pode-se afirmar que não há um embate entre normas, mas sim uma harmonização de "valores". Visando alcançar a aplicação da ponderação na Constituição, resta analisar uma forma especial de interpretação das leis, bem como algumas normas-princípio que socorrem o intérprete quando este se encontra diante de tal conflito aparente.

\section{INTERPRETAÇÃO CONFORME A CONSTITUIÇÃO}

Ponto importante para a compreensão do tema da ponderação de interesses é a forma de exegese aplicada no ordenamento.

Diante do exposto, verifica-se que decorre do princípio da supremacia constitucional e da unidade do ordenamento jurídico que as leis emanadas durante a vigência da Constituição, bem como as já existentes, devem ser interpretadas de acordo com o texto constitucional. Conforme expõe a professora Flávia de Almeida, em sua obra "Interpretação Constitucional e Prestação Jurisdicional", variados são os critérios de exegese, porém, analisando as normas infraconstitucionais pelo método da "interpretação 
conforme a Constituição" 40 , busca-se uma melhor adequação do texto normativo ao intuito constitucional ao qual este se encontra conectado. Dessa maneira, uma norma somente será tida como nula por inconstitucional se tal embate for evidente e não houver possibilidade de adequação com a Carta Magna.

Assim, o intérprete deve buscar sempre o caminho que conduz para a decisão mais adequada, comportando uma maior noção de justiça em função dos princípios básicos que norteiam a Constituição.

Dessa maneira, observa-se que não pode haver a predominância do elemento literal - interpretação dos textos legais de acordo com o sentido próprio de suas palavras - em detrimento dos elementos teleológico interpretação de acordo com o fundamento último da norma, sua finalidade - e sistemático - interpretação das normas de acordo com o contexto no qual se inserem - ou seja, a norma constitucional deve ser compreendida pelo intérprete avaliando seu contexto e respeitando a Lei Maior como unidade. Nas palavras do "Justice" Holmes uma palavra não é um cristal, transparente e imutável, é a pele de um pensamento vivo e pode variar bastante em conteúdo e cores de acordo com as circunstâncias e o tempo em que são usadas. $^{41}$

O professor Vicente Barreto afirma ser a questão da interpretação constitucional uma conditio sine qua non ${ }^{42}$ para a realização de um projeto político-institucional previsto na Carta Magna, ou seja, as proposições e as diretivas expostas na Lei Fundamental somente lograrão êxito em serem alcançadas se as normas infraconstitucionais editadas para aferir completude no ordenamento estiverem em consonância com a Lei Maior e conforme essa forem interpretadas.

\footnotetext{
${ }^{40}$ CASTRO, Flávia de Almeida Viveiros de. Interpretação Constitucional e Prestação Jurisdicional. 01 ed. Lúmen Juris, RJ, 2000, p. 80.

${ }^{41}$ Apud, Ibid. p., 45.
} 
Diante do exposto, nota-se que a característica da unidade da Constituição somada com sua Supremacia "conduz" o intérprete a compreender o ordenamento jurídico como um todo, um conjunto que deve aquiescência a Lei Maior. Assim, a interpretação isolada de cada norma constitucional é uma análise incompleta, pois a Constituição possui uma estruturação, uma harmonia e uma completude, mostrando-se um conjunto e somente assim deve ser entendida. Dessa maneira, a unidade representa uma integração sistêmica das normas contidas na Carta Magna.

Assim, mesmo que se encontre sob a proteção constitucional, nenhum direito pode ser consagrado como "absoluto". Nesse entendimento, os direitos e garantias fundamentais que são assegurados pela Lei Suprema devem ser exercidos em coletividade, onde todos os membros da sociedade podem exercê-los em concomitância e respeito recíprocos.

Aplicando o método em estudo ao próprio texto da Constituição, verifica-se de pronto a impossibilidade de ocorrer uma antinomia real entre suas normas sob pena de comprometer todo o ordenamento jurídico, pois, se assim não fosse, restariam implicadas as bases de validade da Lei Maior que, num paradoxo, se encontrariam enfraquecidas diante da própria Carta Magna.

Para que tanto não ocorra, decorre a assertiva que o intérprete deve realizar um "sopesamento", qual seja a ponderação entre as normas aparentemente colidentes. Para alcançar esse entendimento, cabe analisar os princípios que compõem a base do método da ponderação de interesses.

\section{PRINCÍPIOS CONSTITUCIONAIS}

\footnotetext{
${ }^{42}$ BARRETO, Vicente. Interpretação constitucional e Estado Democrático de Direito. Revista de Direito Administrativo, RJ, no 203, 1996, p. 11/23.
} 
Para uma adequada análise dos princípios constitucionais é necessária uma menção histórica sobre o tema.

O professor Paulo Bonavides aponta três fases de juridicidade dos princípios $^{43}$, sendo: jusnaturalista, positivista e pós-positivista.

Em um primeiro momento, na fase jusnaturalista, observa-se que os princípios eram apenas abstrações filosóficas que interagiam muito pouco com o Direito. Considerados como princípios gerais de direito, possuíam demasiado grau de abstração e sua normatividade era muito questionada.

No início do século XX surge a fase positivista. Os princípios gerais de direito são incorporados aos códigos civis, onde eram considerados normas supletivas, de complementação, encontrando-se no nível inferior da escala normativa. Gordilho Cañas, citado por Bonavides, afirma que os princípios eram apenas "válvulas de segurança", servindo exclusivamente para "impedir o vazio normativo". 44

Já no fim do século XX, os princípios são transportados dos códigos civis para as constituições, no chamado pós-positivismo ${ }^{45}$, onde se convertem em fundamento de toda ordem jurídica ${ }^{46}$, ou seja, a partir das últimas décadas do século passado são acolhidos pelas constituições de maneira harmônica em seus fundamentos, recebendo status de alicerce de todo o sistema constitucional, na qualidade de princípios constitucionais.

Uma divergência doutrinária deve ser exposta. Conforme o professor Peixinho $^{47}$, a Constituição traz diversos princípios - alguns setoriais - tais como os relativos à área econômica, à área da administração pública, dentre outros, que não são princípios gerais de direito Assim, a constituição possui uma esfera de atuação maior, abrangendo princípios gerais de direito e

\footnotetext{
${ }^{43}$ BONAVIDES, Paulo. Op. cit. p. 259.

${ }^{44}$ Apud, Ibid, p., 262.

${ }^{45}$ Ibid. p., 266/283, aponta como pré-cursores do pós-positivismo Ronald Dworkin, Alexy, Muller e Boulanger, que esquematizaram os princípios como normas inseridas no ordenamento e atribuíram a estas eficácia normativa compatível com sua efetiva importância.

${ }^{46}$ Ibid. p, 289.
} 
princípios "exclusivamente" constitucionais. Dessa maneira, o professor Peixinho encontra-se em desacordo com Paulo Bonavides, que, ao seu turno, defende haver uma integração dos princípios gerais de direito em função de sua constitucionalização, entendendo ocorrer uma "unificação dos princípios gerais de Direito em torno dos princípios constitucionais" ${ }^{\natural 8}$. Bonavides afirma que, na "revolução principial" os princípios constitucionais representam os princípios gerais de direito. Em posição contrária, entretanto, Gordilho Cañas afirma que há uma separação, pois ocorre uma mudança na natureza do princípio. Explica Gordilho que, com os princípios constitucionais, a Lei Fundamental incorpora uma "ordem objetiva de valores"49, imbuindo os princípios de uma "superlegalidade material" $" 50$, ou seja, a Constituição seria fonte primária em sua consideração formal e também fonte material.

É certo que os princípios possuem uma valoração maior hoje em dia, pois os aplicadores do direito atribuem devida importância à sua eficiência perante o ordenamento.

No intuito de alcançar a técnica da ponderação na Constituição brasileira, cabe estudar alguns princípios constitucionais que muito contribuem para o intérprete na utilização da ponderação, sendo estes, a proporcionalidade e a razoabilidade.

\subsection{PROPORCIONALIDADE (adequação, necessidade e proporcionalidade em sentido estrito)}

\footnotetext{
${ }^{47}$ PEIXINHO, Manuel Messias. Op. Cit. p., 104.

${ }^{48}$ BONAVIDES, Paulo, Op. cit. p., 291.

${ }^{49}$ Apud. Ibid. p., 290.

${ }^{50}$ Apud. Ibid. p., 290.
} 
Primeiramente, cabe ressaltar que a aplicação do princípio da proporcionalidade é comum na seara administrativa, porém, atualmente, vem sendo muito utilizado no direito constitucional.

Para uma aplicação concisa, o princípio da proporcionalidade envolve três elementos básicos que devem ser avaliados, garantindo sua eficácia e eficiência: a adequação, a necessidade e a proporcionalidade em sentido estrito $^{51}$.

Por meio da adequação, a medida administrativa ou legislativa emanada do Poder Público deve ser apta para alcançar os fins a que visam. Aqui, verifica-se a idoneidade do ato público para a consecução da finalidade perseguida pelo Estado. O intérprete deve realizar uma avaliação do meio utilizado versus o fim colimado, verificando a vontade do legislador perante a "capacidade" da norma em cumprir tal intuito.

Através do segundo elemento - a necessidade ou exigibilidade - o Poder Público deve adotar sempre a medida menos gravosa para alcançar seu objetivo. Assim, a medida utilizada deve ser compatível com o decoro, observando o mínimo de invasão e de afetação nos direitos e garantias constitucionais. O Estado deve buscar cumprir suas funções sem violar ou, em último caso, violando da forma mais branda possível os direitos do cidadão.

Já a proporcionalidade em sentido estrito envolve uma análise da relação "custo-benefício" da norma, ou seja, o ônus imposto pela norma para seu cumprimento deve ser menor do que seu benefício gerado. O intérprete deve ponderar acerca dos interesses que são protegidos com a medida diante dos bens jurídicos restringidos ou sacrificados por esta.

Observada a sua base de formação, cabe estudar algumas funções inerentes ao princípio em questão.

\footnotetext{
${ }^{51}$ SARMENTO, Daniel. A Ponderação de Interesses na Constituição Federal. 01 ${ }^{\mathrm{a}}$ ed. Lúmen Júris. Rio de Janeiro. 2002, p., 87.
} 
Dentre seus desdobramentos, destaca-se a função de compatibilizar as realidades sociais, excluídas por um formalismo jurídico, com as necessidades de atualização do Direito Constitucional, que deve ser direcionado para a sociedade e dotado da mais larga esfera possível de incidência. Assim, tal princípio se impõe em barreira ao arbítrio e a qualquer contrariação de valor e norma constitucional.

Dessa maneira, o princípio da proporcionalidade traduz para o Estado a necessidade de que seus atos sejam adequados e proporcionais às relações que regem, ou seja, "visa à contensão de arbítrios e a moderação do exercício do poder, em favor da proteção dos direitos do cidadão". ${ }^{52}$

Outra função inerente ao princípio em estudo trata do controle das leis por parte do Poder Judiciário, produzindo uma controvertida ascendência do juiz, que é o responsável pela prestação jurisdicional, sobre o legislador. No entendimento de Bonavides, os poderes legislativo e judiciário devem manter seu equilíbrio constitucional ante a aplicação do princípio. Assim, a utilização da proporcionalidade tem de ser bem apurada para evitar um desrespeito à separação dos poderes e comprometer tal balanço. O autor realiza uma crítica, aludindo a um "Estado de Juízes" arbítrio de suas próprias vontades, mas sim em respeito à Constituição como unidade. Entende ainda que, através do princípio da proporcionalidade, o legislador se torna um "funcionário da Constituição",54, delimitando o espaço de atuação do Poder Legislativo, proporcionando uma maior concretude na aplicação dos direitos fundamentais.

O controle das leis por parte do Poder Judiciário, através do princípio da proporcionalidade, é uma das grandes críticas realizadas pela doutrina. A utilização do princípio possui um grande subjetivismo do aplicador do direito

\footnotetext{
${ }^{52}$ Ibid. p., 77.

${ }^{53}$ BONAVIDES, Paulo Op. cit. p., 420.

${ }^{54}$ Ibid. p., 424.
} 
que deve observar cautela para não realizar uma disparidade entre os poderes, quando da avaliação da adequação, necessidade e ponderação. ${ }^{55}$

Mesmo ante as diversas críticas, o princípio da proporcionalidade recebe, cada vez mais, atenção por parte da doutrina e dos tribunais. Seu alto grau de subjetividade atribuída ao intérprete é decorrente de sua natureza, pois se trabalha com "valores". Porém, utilizando-se de parâmetros como a adequação, a necessidade e a ponderação em sentido estrito, propicia-se ao aplicador do direito a possibilidade de avaliar a relação de causalidade entre meio e fim, realizando uma correta interpretação constitucional diante de um caso concreto difícil.

O princípio em estudo mostra-se fundamental para a concretização da técnica da ponderação de interesses constitucionais, pois seu raciocínio, em suas três fases subseqüentes, somado ao princípio da razoabilidade, é aquele que se deve empregar na ponderação. A técnica da ponderação e a proporcionalidade estão necessariamente ligadas, pois através desse princípio o intérprete deve fazer um "sopesamento" da matéria tratada, solucionando ou atribuindo a menor afetação possível ao conflito aparente entre direitos e garantias fundamentais.

\subsection{RAZOABILIDADE}

O princípio da razoabilidade possui diversos sentidos, podendo ser aplicado em todo o ordenamento jurídico. Verifica-se a razoabilidade de uma interpretação, de uma restrição, do fim de uma norma, dentre outras,

\footnotetext{
${ }^{55}$ Conforme SARMENTO, Daniel, Op. cit. p. 90. O princípio da proporcionalidade possui uma trajetória modesta no ordenamento jurídico pátrio, uma vez que o Poder Judiciário, com uma visão rígida, não realiza uma aplicação plena de tal norma-princípio, evitando ao máximo afetar o princípio da Separação dos Poderes.
} 
mostrando-se de pronto um princípio bastante elástico e com alcance abrangente $^{56}$.

Para a análise da ponderação, o princípio da razoabilidade deve ser estudado sobre três desdobramentos principais ${ }^{57}$ : eqüidade, congruência e equivalência.

O princípio da "razoabilidade como eqüidade" exige do intérprete uma harmonização entre os fatos do caso concreto e a norma geral a ser aplicada na solução de tal problema. A razoabilidade age como uma diretriz que proporciona a possibilidade de relacionar as nuanças fatídicas com a norma. Nas palavras de Humberto Ávila: "Na aplicação do Direito deve-se presumir o que normalmente acontece, e não o contrário" ${ }^{98}$, ou seja, no cotidiano jurídico a razoabilidade mostra-se como um princípio que positiva uma presunção de veracidade aos atos corriqueiros, não sendo necessária uma discussão profunda sobre atos que mostram-se meramente formais ${ }^{59}$. Assim, não pode haver por parte do intérprete uma "presunção de má-fé".

Dessa maneira, para uma coerente utilização da razoabilidade, devem ser avaliadas as características peculiares do caso concreto, não cabendo, por parte do intérprete, uma aferição genérica e abstrata, criando "padrões" de incidência do princípio.

Nesse sentido, verifica-se o segundo desdobramento do princípio, uma vez que a "razoabilidade como congruência" aponta para a harmonização das normas com suas condições externas, ou seja, o intérprete deve analisar a norma geral em face da conjuntura social a que se dirige.

\footnotetext{
${ }^{56}$ Cumpre ressaltar que a razoabilidade vem sendo observada pelos tribunais no Brasil há algum tempo, porém, com a emenda constitucional número 45, de 08.12 .04 , o princípio em tela tem um de seus efeitos expressamente positivado em nossa Constituição, dispondo a Carta Magna em seu artigo 50, LXXVIII: "a todos no âmbito judicial e administrativo são assegurados a razó́vel duração do processo e os meios que garantam a celeridade de sua tramitação". Note-se que a razoabilidade, como princípio constitucional, não tem sua aplicação restringida "ao tempo de duração" de um processo, sendo esta apenas um de seus desdobramentos.

${ }^{57}$ ÁVILA, Humberto. Op. cit. p., 103.

${ }^{58}$ Ibid. p., 104.
} 
A norma geral não pode ser interpretada de forma isolada, desvinculando esta da realidade social atual. Assim, exige-se do aplicador do direito a realização de um confronto com parâmetros externos a ela ${ }^{60}$.

Depois de observadas a eqüidade e a congruência, verifica-se o surgimento de duas grandezas diante do aplicador do direito, quais sejam: a medida a ser adotada e o critério que irá dimensioná-la.

Assim, o terceiro desdobramento refere-se a "razoabilidade como equivalência", onde o princípio da razoabilidade norteia o intérprete para uma melhor adequação e harmonização entre a medida cabível ao caso e o critério que irá dimensionar tal medida.

Com a aplicação de seus desdobramentos - eqüidade, congruência e equivalência - o princípio da razoabilidade adquire certo grau de solidificação, descaracterizando a abstração atribuída pelo intérprete na análise de um caso concreto. Com isso, o aplicador do direito pode verificar a relação entre uma qualidade - critério intrínseco da medida a ser adotada - e a própria medida aplicada ao caso.

Diante do exposto, verifica-se que as normas-princípio ora apresentadas - proporcionalidade e razoabilidade - possuem grande importância para a realização de uma ponderação de interesses na Constituição, não podendo o intérprete avaliar um caso concreto privando-se de um dos princípios estudados.

\footnotetext{
${ }^{59}$ No Brasil pode-se observar a aplicação do princípio em alguns casos concretos. A respeito cabe citar STF, 2 ${ }^{\mathrm{a}}$ Turma, RE 208.685-1, rel. Min. Ellen Gracie, DJ 22.08.2003.

${ }^{60}$ Como exemplo: Apud, ÁVILA, Humberto. Op. cit. p., 108, STF, Tribunal Pleno, ADIn 1.753-2, rel. Min. Sepúlveda Perence DJU 12.06.1998.
} 


\section{CAPÍTULO III - DA PONDERAÇÃO}

\section{A TÉCNICA DA PONDERAÇÃO DE INTERESSES}

Para compreender a técnica da ponderação de interesses na Constituição, primeiramente cabe analisar a sua finalidade e verificar a possibilidade de ocorrência de um aparente conflito na Lei Maior.

Com base na teoria escalonada do ordenamento jurídico verifica-se que as normas possuem certo grau de hierarquia entre si, porém, estudando uma norma de forma isolada do ordenamento que compõe, não há como o intérprete realizar uma análise de valoração acerca de uma "hierarquia interna da própria norma”, pois faltaria um parâmetro de comparação e a norma seria plena em sua eficácia, mesmo que contivesse algum conflito ${ }^{61}$. Dessa maneira, para que tanto não ocorra, a Constituição mostra-se como uma base fundamental - um parâmetro de comparação - em socorro para a solução de tal embate, servindo de modelo.

A sociedade contemporânea é composta por uma grande diversidade cultural, assim, divergentes entendimentos e conclusões sobre um mesmo assunto podem ser observados. Concepções variadas podem inclusive ser encontradas no tocante a um mesmo direito e sua aplicação.

A Constituição - como Lei Suprema - comporta o sistema de valores essenciais e a ordem administrativa e política do Estado irradiando suas normas por todo o ordenamento jurídico.

Analisando o problema do conflito de normas e tendo por fundamento a Supremacia e Unidade Constitucionais, bem como a grande diversidade social,

\footnotetext{
${ }^{61}$ Vide capítulo I, ponto 1.
} 
cabe indagar se essa questão não poderia se reproduzir na própria Constituição. E se o fizesse, como se daria sua solução, uma vez que na Lei Maior o intérprete encontraria o ponto controvertido e a própria base de comparação.

Devido ao pluralismo de idéias sociais que se encontram abrangidas na Constituição surgem os aparentes embates das normas, logo, os conflitos podem ocorrer em nível Constitucional. Diante disso, a ponderação de interesses tem por escopo principal a solução de tais conflitos.

Cumpre ressaltar que o intérprete, na ponderação, trabalha com "valores" - abstrações que não podem ser quantitativamente mensuráveis logo, juízos axiológicos. Diante disso, a ponderação de interesses não se constitui em um método matemático de solução dos aparentes conflitos dos princípios constitucionais, mas deve, entretanto, almejar uma "maior objetividade e racionalidade possíveis" $" 62$.

A técnica em estudo, em sua formação básica, vale-se da estrutura tridimensional do Direito, envolvendo três aspectos já vistos, quais sejam: normativo (ordenamento e ciência do Direito), fático (efetividade social) e axiológico (valor de justiça) ${ }^{63}$. A interação desses aspectos forma uma unidade que atribui dinamicidade ao Direito, uma vez que este deve buscar corresponder às estruturas sociais contemporâneas.

A ponderação de interesses é composta por fases, as quais o intérprete deve incumbir-se de cumprir para alcançar um resultado prático para o caso concreto.

$\mathrm{Na}$ primeira fase - "preparação da ponderação"64 - o aplicador do direito deve buscar identificar o conflito normativo, avaliando todos os

\footnotetext{
${ }^{62}$ SARMENTO, Daniel. Op. cit. p., 99.

63 Ibid. p., 99. Note-se que essa formação estrutural refere-se ao modelo de técnica de ponderação de interesses apresentada por Daniel Sarmento, onde se observa in verbis: "Pode-se então afirmar que a ponderação de interesses, pelo menos na versão ora defendida, ostenta uma estrutura tridimensional, pois compreende os três elementos em que se decompõe o fenômeno jurídico: fato, norma e valor." Acerca da estrutura tridimensional do Direito vide capítulo I, ponto 1, pág.8.

${ }^{64}$ ÁVILA, Humberto. Op. cit. p., 95.
} 
elementos e argumentos, indicando o que está sendo objeto da ponderação. Conforme o professor Sarmento, se o embate ocorrer entre normas-regra não será alvo de uma ponderação, devendo ser resolvido através dos critérios clássicos de solução ${ }^{65}$, divergindo assim, do entendimento de Humberto Ávila, que afirma serem as regras também passíveis de uma ponderação ${ }^{66}$. Daniel Sarmento afirma que somente há necessidade de usar a técnica da ponderação se houver dois ou mais princípios aparentemente colidentes, cabendo ao intérprete identificá-los e verificar a melhor forma de harmonizá-los no caso concreto, obedecendo e realizando uma "unidade constitucional". Conforme Roberto Bin, fazer esta análise significa verificar a sobreposição de alcances dos direitos conflitantes, determinando qual seu espaço de atuação em confronto com o outro ${ }^{67}$.

No que tange aos direitos fundamentais esta verificação do alcance de uma norma em detrimento a outra corresponde à identificação dos "limites imanentes de cada direito"68. Tal "limite imanente" deve ser apurado antes de seguir para a próxima fase, uma vez que os conflitos somente se caracterizam se os fatos estiverem contidos dentro dos limites de mais de um princípio. Ressalte-se que esse "limite" é usado pela doutrina no tocante aos direitos fundamentais, porém, o professor Sarmento afirma que este pode ser estendido para normas constitucionais de outra categoria.

Seguindo a análise das fases da ponderação, se o intérprete apurar a ocorrência do aparente conflito constitucional, deve passar à "realização da ponderação",69, ou seja, à ponderação propriamente dita.

Nesta segunda etapa, o aplicador do direito deve verificar a relação de primazia entre os princípios conflitantes. Diante dos fatos apresentados no caso

\footnotetext{
${ }^{65}$ Vide capítulo I, ponto 3.

${ }^{66}$ ÁVILA, Humberto. Op. cit. p., 44.

${ }^{67}$ Apud, SARMENTO, Op. cit. p., 100.

${ }^{68}$ Ibid. p., 100.

${ }^{69}$ ÁVILA, Humberto. Op. cit. p., 96.
} 
concreto, o intérprete deve "impor compressões",70 aos princípios que estão em embate, buscando encontrar um "ponto ótimo"71 entre estes, no qual a restrição imposta a cada um dos interesses tutelados pelos princípios em questão seja a menor possível e ambos possam coexistir.

Deve-se avaliar o "peso genérico"72 de cada princípio, ou seja, o intérprete tem que buscar a relação do princípio com a Constituição, verificando seus efeitos e desdobramentos. O fato de não haver uma hierarquia entre as normas constitucionais não implica dizer que a Constituição confira a mesma relevância a todos os interesses nela contidos.

Após definir o "peso genérico", que é apenas o norteador - indicativo do "peso específico"73 de cada princípio, o aplicador do direito deve apurar o próprio "peso específico", que somente pode ser avaliado diante de cada caso concreto, verificando os fatos expostos no caso concreto. Assim, percebe-se que a solução do conflito é casuística.

Ao determinar o "peso específico", o intérprete encontra o "valor" que a norma possui diante do caso concreto específico. Com isso, implicitamente e por comparação negativa, encontra também a "força" com que deve incidir a restrição a ser imposta ao princípio de "menor valia” no caso concreto.

Alcançadas estas fases, Humberto Ávila aponta a última etapa "reconstrução da ponderação" formulação de regras de relação" ${ }^{\text {75 }}$ concretizar a ponderação. Cabe ao aplicador do direito atingir uma moderação, onde os princípios colidentes possam coexistir, o embate seja solucionado e a restrição imposta aos princípios seja a menor possível.

\footnotetext{
${ }^{70}$ SARMENTO, Daniel. Op. cit. p., 102.

${ }^{71}$ Ibid. p., 102.

${ }^{72}$ Ibid. p., 103.

${ }^{73}$ Ibid. p., 104.

${ }^{74}$ ÁVILA, Humberto. Op. cit. p., 96.

${ }^{75}$ Ibid. p., 96.
} 
Para chegar em uma moderação que cumpra com os objetivos da ponderação, as restrições impostas devem estar de acordo com os princípios da proporcionalidade - necessidade, adequação e proporcionalidade em sentido estrito - e da razoabilidade - eqüidade, congruência e equivalência encontrando ainda parâmetros limitativos no princípio da dignidade humana e no fato de que o intérprete somente pode agir no que estiver em confronto, respeitando os "limites imanentes" de cada princípio e trazendo um equilíbrio para o conflito.

O professor Sarmento, no mesmo entendimento de Humberto Ávila, ressalta três desdobramentos principais no tocante ao resultado da ponderação que deve ser almejado pelo aplicador do direito. A restrição imposta a cada interesse em questão só se justificará na medida em que: 1- mostrar-se apta para garantir a sobrevivência do interesse contraposto, ou seja, não pode extinguir ou ameaçar a existência do princípio restringido, 2- não houver solução menos gravosa, ou seja, a imposição deve ser apenas o bastante para solucionar o aparente embate, 3- o benefício alcançado com a restrição a um interesse deve compensar o grau de sacrifício imposto ao interesse antagônico. ${ }^{76}$

Diante destas fases procedimentais apresentadas, podem-se verificar algumas características e desdobramentos da técnica da ponderação de interesses na Constituição.

Conforme Humberto Ávila "a ponderação, sem uma estrutura e sem critérios materiais, é instrumento pouco útil para a aplicação do Direito",77, porém, diante das fases apresentadas, a técnica da ponderação busca cumprir seu desiderato baseada em critérios o mais objetivos e racionais possíveis. Ressaltando-se que ponderar é buscar aferir o alcance e a extensão dos direitos

\footnotetext{
${ }^{76}$ SARMENTO, Daniel. Op. cit. p., 104. e ÁVILA, Humberto. Op. cit. p., 112.

${ }^{77}$ ÁVILA, Humberto. Op. cit. p. 94.
} 
fundamentais colidentes, destacando uma primazia de eficácia entre estes, harmonizando e adequando os interesses no caso concreto.

A ponderação somada a uma interpretação sistêmica da Lei Suprema visa evitar o abuso de um direito ou ainda o exercício exorbitante das liberdades individuais, uma vez que as dimensões fáticas dos casos concretos possuem muita importância. $\mathrm{O}$ intérprete deve ter o cuidado de avaliar cada problema específico, para então, diante dos fatos apresentados, realizar um sopesamento direcionado entre cada princípio aparentemente confrontante.

Por certo, a ponderação pode ser considerada um método bastante elástico, por possuir uma grande maleabilidade de aplicação, sendo extremamente dinâmica e produtiva na concretização do conflito constitucional. Entretanto, essa qualidade também produz uma face negativa, onde se verifica que a ponderação possui difícil utilização devido a sua fluidez, mesmo que o intérprete tenha por base a metodologia estudada, pois, conforme afirma Sarmento, "sua atuação estará necessariamente condicionada por uma pré-compreensão do problema - uma percepção inicial, ainda difusa e sentimental, da sua solução ideal - da qual ele, como ser humano, não consegue se libertar" ${ }^{78}$.

Não implica, porém, dizer que o método possui uma falha em seu alicerce, pois esta é a proposição da técnica da ponderação: tentar, com meios objetivos e racionais, descaracterizar a solução atribuída ao caso concreto de qualquer subjetividade ou sentimento pessoal.

Nessa linha de entendimento, ao realizar a prestação jurisdicional, o aplicador do direito deve respeito ao ordenamento e à Constituição como "um todo", uma vez que sua legitimidade de atuação decorre deste, logo, nenhuma ponderação pode reger-se por elementos externos ao ordenamento ou alheios aos fatos do caso concreto. Assim, não pode o intérprete desconsiderar os dados normativos, que possuem grande importância para a solução do suposto 
embate constitucional, pois afastar a força normativa da Constituição seria desproteger o cidadão de suas garantias fundamentais. ${ }^{79}$

Diante do exposto, cabe estudar algumas divergências doutrinárias e conceitos inerentes à técnica da ponderação de interesses.

\subsection{PONDERAÇÃO E NORMAS}

A doutrina discute se o método da ponderação de interesses seria de aplicação privativa das normas-princípio ou se este pode ser observado junto às normas em geral, divergindo no entendimento.

Conforme Sarmento, as normas-regra não são objeto de ponderação, uma vez que seu conflito deve ser resolvido através dos critérios clássicos já vistos - cronológico, hierárquico e de especialidade. Assim, se duas regras incidem no caso concreto de forma oposta, uma delas não será aplicada, cabendo seu afastamento da solução do conflito. Dessa maneira, somente os interesses abrigados por princípios constitucionais explícitos ou implícitos podem ser objeto de ponderação. ${ }^{80} \mathrm{Na}$ mesma linha de entendimento, Eros Roberto Grau afirma que, em alguns casos, os princípios desdobram-se de regras jurídicas. Assim, sempre que estes princípios forem objetos de uma ponderação e a restrição incidir sobre eles, as regras das quais surgem não deverão ser observadas no caso em questão.

\footnotetext{
${ }^{78}$ SARMENTO, Daniel. Op. cit. p., 103.

${ }^{79}$ O professor Humberto Ávila aponta ainda a "proibição de excesso" como um desdobramento da ponderação de interesses. Esse postulado proíbe a restrição excessiva de qualquer direito fundamental. Não necessitando da relação de causalidade entre meio e fim que deve ser observada na ponderação, bastando incidir uma restrição mais severa a um direito fundamental. Assim, poderia inclusive ser aplicado sem a observação do princípio da proporcionalidade e vice-versa. Op. cit. p., 97.

${ }^{80}$ SARMENTO, Daniel. Op. cit. p., 42.
} 
Humberto Ávila, em entendimento divergente dos autores citados, afirma que as normas-regra também podem ser sopesadas, bastando para tanto, diante da análise do caso concreto, a observação de tal necessidade por parte do intérprete. Nesse sentido, dispõe em sua obra:

"Com efeito, a ponderação não é método privativo de aplicação dos princípios. A ponderação ou balanceamento (weighing and balancing, Abwägung), enquanto sopesamento de razões e contra-razões que culmina com a decisão de interpretação, também pode estar presente no caso de dispositivos hipoteticamente formulados, cuja aplicação é preliminarmente havida como automática (no caso de regras, consoante o critério aqui investigado)". 81

Dessa maneira, o professor Humberto ensina que o sopesamento de motivos expostos no caso concreto, favoráveis ou não, pode ser realizado independente de incidirem sobre princípios ou regras, uma vez que, a “dimensão de peso" não seria característica privativa das normas-princípio. ${ }^{82}$

Outro ponto de destaque acerca da técnica da ponderação de interesses diz respeito a possível criação de "padrões" diante dos julgados observados, surgindo os institutos da "ponderação abstrata" e da "ponderação $A d$ Hoc".

\subsection{PONDERAÇÃO ABSTRATA E PONDERAÇÃO Ad Hoc}

A doutrina que trata da matéria busca dividir a ponderação em dois gêneros, observando para tanto sua forma de incidência, avaliando se esta ocorre aplicada a um caso específico ou se incide de maneira desvinculada de fatos concretos.

\footnotetext{
${ }^{81}$ ÁVILA, Humberto. Op. cit. p., 44.

${ }^{82}$ Vide capítulo I, ponto 2 .
} 
A "ponderação abstrata" não envolve a ocorrência de um caso concreto, refere-se a uma ponderação genérica realizada pela doutrina e jurisprudência que alcançam alguns consensos sobre determinadas matérias. $\mathrm{O}$ professor Sarmento, consoante com Robert Bin, entende que não se trata de uma ponderação de interesses em sua forma, pois "guarda as características essenciais da interpretação jurídica tradicional”, ${ }^{, 3}$, sendo, assim, apenas uma interpretação sistêmica da Constituição.

Paralelamente à "ponderação abstrata", verifica-se uma ponderação que mantém relação direta com a apresentação de casos concretos. A "ponderação $A d H o c$ " é aquela realizada a partir da análise de um caso concreto e suas peculiaridades fatídicas.

Cumpre ressaltar que as "ponderações ad hoc" não "criam" "ponderações abstratas" com a constância de casos julgados, pois, por ser a ponderação uma técnica bastante específica, as pequenas nuanças nos fatos podem implicar diferentes resultados. Conforme observou Karl Larenz a comparação de casos possibilita analogias e porventura uma certa tipificação dos casos; a 'ponderação de bens' será desse modo aliviada, mas não se tornará supérflua. ${ }^{84}$ Com isso, verifica-se que as "ponderações ad hoc" atribuem para a técnica da ponderação de interesses um limitativo, diminuindo a subjetividade de casos análogos futuros, sem, contudo, conduzir a própria "ponderação ad hoc" para uma "extinção".

\subsection{FUNDAMENTAÇÃO - EXPOSIÇÃO DE MOTIVOS -}

\footnotetext{
${ }^{83}$ SARMENTO, Daniel. Op. cit. p., 110. Dispõe em seu livro, como exemplo de ocorrência no ordenamento jurídico pátrio, no campo do direito penal, a prisão processual que antecede o trânsito em julgado da sentença penal condenatória, onde se encontram em conflito a "presunção de inocência" versus a "segurança pública".

${ }^{84}$ Apud, Ibid. p., 111.
} 
Um ponto de destaque concernente à ponderação de interesses e sua validação são os motivos expostos - fundamentação - na prestação jurisdicional do Estado.

Concluindo as fases procedimentais da ponderação de interesses, o juiz possui o dever de demonstrar os motivos de fato e de direito que o levaram à determinada convicção. ${ }^{85}$ Sem a observância deste elemento, a prestação jurisdicional é nula. ${ }^{86}$

Dessa maneira, a fundamentação representa uma garantia constitucional, pois o juiz encontra-se impedido de realizar um julgamento arbitrário ou caprichoso, impondo-lhe respeito à ordem jurídica. ${ }^{87}$

A exposição de motivos mostra-se um ponto especial de esclarecimento na decisão de uma ponderação de interesses devido ao grau de subjetividade imbuído nesta. Conforme Ângelo Antonio Cervati, cabe ao Poder Judiciário um ônus de motivação jurídica, que requer um empenho tanto maior quanto mais as decisões se fundem na utilização de parâmetros elásticos de valoração ou em cláusulas constitucionais formadas de modo aberto. ${ }^{88}$ Assim, a fundamentação deve ser proporcional ao grau de subjetividade imbuído na decisão.

Como outro aspecto da fundamentação - exposição de motivos e fundamentação crítica - verifica-se a possibilidade de realizar o controle acerca da ponderação de interesses, verificando a razoabilidade, a proporcionalidade, bem como os parâmetros limitativos inerentes a esta.

\footnotetext{
${ }^{85}$ A motivação das decisões judiciais no ordenamento jurídico pátrio recebe status constitucional, dispondo a Carta Magna em seu artigo 93, IX, "todos os julgamentos dos órgãos do Poder Judiciário serão públicos, e fundamentadas todas as decisões, sob pena de nulidade, podendo a lei, se o interesse público o exigir, limitar a presença, em determinados atos, às próprias partes e a seus advogados, ou somente a estes; ;".

${ }^{86}$ JÚNIOR, Humberto Theodoro. "Curso de Direito Processual Civil". Volume I, 39a ed. Forense RJ, 2003, p., 457.

${ }^{87}$ SARMENTO, Daniel. Op. cit. p., 117.
} 


\section{O PRINCÍPIO DA DIGNIDADE HUMANA E A PONDERAÇÃO}

Primeiramente, para compreender a relação entre o princípio da Dignidade Humana e a técnica da ponderação cabe traçar o surgimento e a interação de tal princípio com o Direito.

A dignidade humana sempre pairou sobre os estudos filosóficos, porém, adquire maior foco com a filosofia dos sofistas $^{89}$, que buscavam separar e destacar o Homem como a base de suas análises em face da lei, da justiça e da natureza.

Protágoras, com a máxima "homo-mensura" ${ }^{90}$, afirma que o homem deve ser considerado como a medida de todas as coisas, criando um relativismo em torno da questão dos direitos e da justiça frente ao Estado, pois o homem seria o fim direto do Estado e do Direito.

Seguindo a mesma linha, já no segundo período da filosofia moderna, Immanuel Kant afirma que o homem não deve ser submetido a outro homem. Logo, o que caracteriza o ser humano e o faz dotado de dignidade especial é que ele nunca pode ser um meio para os outros seres, mas sempre um fim em si mesmo. ${ }^{91}$

Diante disso, Kant entende que o homem tem valor absoluto, não podendo, por conseguinte, ser usado como instrumento de parâmetro para algo, e, justamente por isso, tem dignidade, é pessoa.

A exaltação do valor da pessoa humana conduziu a uma afirmação dos direitos específicos de cada homem. Assim, a dignidade da pessoa humana

\footnotetext{
${ }^{88}$ Apud, Ibid. p., 119.

${ }^{89}$ Dentre os filósofos de destaque do período mencionado pode-se citar: Protágoras, Górgias, Crítias, Antifonte, que contribuem para o desenvolvimento do princípio em questão, bem como para sua interação com o Direito. Observado em http://www.reinerio.hpg.ig.com.br/Sofistas.htm.

90 Trecho observado em http://www.educ.fc.ul.pt/docentes/opombo/hfe/momentos/escola/sofistas/protagoras.htm. e http://www.reinerio.hpg.ig.com.br/Sofistas.htm. Para um aprofundamento no pensamento de Protágoras cabe a leitura de sua obra "A verdade".
} 
pode ser compreendida como o centro essencial dos direitos fundamentais, uma fonte, que lhe confere unidade de sentido e valor.

Com o amadurecimento do pensamento dos filósofos e sua difusão social, o princípio da Dignidade Humana deixa de ser apenas uma teoria filosófica abstrata para ser um postulado positivado, incorporado ao Direito na Declaração Universal dos Direitos Humanos ${ }^{92}$, aprovada pela Assembléia Geral das Nações Unidas de 10 de dezembro de 1948.

Por tratar-se de um princípio bastante abstrato e abrangente, "sua fluidez permite uma vasta aplicação"93, irradiando suas características por toda a constituição e legislação infra, norteando o posicionamento que deve ser adotado pelo intérprete.

Sua esfera de incidência alcança todo o ordenamento jurídico e encontra na constituição, entendida como unidade, um alicerce de fundamentação ${ }^{94}$.

Em sua completude, o princípio envolve tanto os direitos como as garantias constitucionais que versam sobre a vida, a integridade (física e moral) e o respeito humano, inclusive salvaguardando os direitos da

$91 \quad$ Conforme $\quad$ exposto em $\quad$ http://www.cobra.pages.nom.br/fmp-kant.html
http://www.chh.ufsc.br/ simpozio/novo/2216y660.htm .

92 Apesar de longa, é válida a citação do texto da Declaração Universal que envolve os direitos acerca da Dignidade Humana.

Preâmbulo

Considerando que o reconhecimento da dignidade inerente a todos os membros da família humana e seus direitos iguais e inalienáveis é o fundamento da liberdade, da justiça e da paz no mundo;

Considerando que, na Carta, os povos das Nações Unidas proclamam, de novo, a sua fé nos direitos fundamentais do homem, na dignidade e no valor da pessoa humana, na igualdade de direitos dos homens e das mulheres e se declararam resolvidos a favorecer o progresso social e a instaurar melhores condições de vida dento de uma liberdade mais ampla;

Art. $1^{\circ}$. Todos os homens nascem livres e iguais em dignidade e direitos. São dotados de razão e consciência e devem agir em relação uns aos outros com espírito de fraternidade.

Art. $3^{\circ}$. Quem trabalha tem direito a uma remuneração eqüitativa e satisfatória, que lhe permita e à sua família uma existência conforme com a dignidade humana, e completada, se possivel, por todos os outros meios de proteção social.

${ }^{93}$ SARMENTO, Daniel. Op. cit. p. 58.

94 No ordenamento jurídico pátrio, apesar da incidência do princípio em diversos pontos da constituição, o legislador constituinte destacou e instituiu o princípio em estudo no artigo $1^{\circ}$, III, $\mathrm{CF} / 88$, como um dos fundamentos do Estado Brasileiro. Isso importa dizer que o Estado existe em função de todas as pessoas e não estas em função do Estado. Assim, a dignidade humana é um modelo de base para cada ação do Poder Público e um dos elementos de avaliação de atuação do Estado brasileiro. 
personalidade que configuram "um círculo de direitos necessários; um conteúdo mínimo e imprescindivel da esfera jurídica de cada pessoa" ${ }^{, 5}$, incidentes sobre a sua honra, liberdades física e psicológica, nome, imagem e intimidade de sua vida privada, delineando as condições básicas para a manutenção de um caráter e decoro sociais.

Ainda com base na dignidade da pessoa humana, verifica-se que não é possível a redução do homem à condição de mero objeto do Estado ou de terceiros. Sua consagração constitucional resulta na obrigação do Estado em garantir à pessoa humana um patamar mínimo de recursos, capaz de prover-lhe a subsistência.

A dignidade da pessoa humana, como visto, implica considerar o homem como o centro do universo jurídico. Esse reconhecimento, que não se dirige a indivíduos específicos, abrange todos os seres humanos e cada um destes individualmente considerados. Em decorrência disso, a projeção dos seus efeitos na ordem jurídica não pode incidir, em uma primeira análise, de modo diverso ante a duas pessoas. Diante dessa assertiva, logo surge a dúvida: seria ou não o princípio em questão passível de uma ponderação axiológica por parte do aplicador do direito?

Certamente! Em situações específicas, o interesse coletivo pode vir a prevalecer, justificando uma proporcional restrição aos direitos fundamentais. Note-se que o intérprete não deve impor sobre o princípio da dignidade humana algum fator que venha amesquinhá-lo ou restringi-lo em suas garantias fundamentais além do mínimo necessário para a solução do aparente conflito. O princípio em questão deve ser compreendido e respeitado como princípio fundamental, porém, não deve ser considerado absoluto, como nenhum direito o é.

A solução há de ser buscada em cada caso, de acordo com as circunstâncias apresentadas. Deve-se procurar a harmonia dos mencionados

\footnotetext{
${ }^{95}$ PINTO, Carlos Alberto da Mota. Teoria geral do direito civil. Coimbra Editora, $3^{\text {a }}$ d., 1985. p. 207.
} 
valores, realizando uma ponderação na qual se avaliará o que toca ao indivíduo e o que cabe ao todo, buscando a menor afetação para ambas as partes em seus direitos mais básicos. Assim, conforme o professor Sarmento, "a dignidade da pessoa humana afirma-se como o principal critério substantivo na direção da ponderação de interesses constitucionais" ${ }^{" 96}$.

O professor Sarmento também afirma que o princípio em questão jamais pode ceder em face de outro princípio constitucional, somente podendo ser "ponderado" se o aparente embate ocorrer entre direitos fundamentais, englobados pelo próprio princípio da dignidade humana. Em posição contrária, verifica-se o entendimento de Robert Alexy, que afirma ser a dignidade da pessoa humana suscetível de ponderação ante outros princípios constitucionais, dependendo apenas da análise do caso concreto.

Importante ressaltar que, antes de qualquer interpretação do aplicador do direito, cabe a este verificar a constitucionalidade de toda e qualquer ação do ente estatal frente ao princípio em estudo, sob pena de inconstitucionalidade por violar a dignidade da pessoa humana, devendo avaliar se o ser humano é tomado como fim em si mesmo ou como instrumento, como um meio para alcançar outros objetivos.

Diante do exposto, percebe-se que a dignidade da pessoa humana, retratando o reconhecimento de que o indivíduo há de constituir o objetivo primacial da ordem jurídica, traduz a repulsa constitucional às práticas, imputáveis aos poderes públicos ou aos particulares, que visem expor o ser humano a uma posição de desigualdade perante os demais, a desconsiderá-lo como pessoa, reduzindo-o à condição de coisa, ou ainda a privá-lo dos meios necessários à sua manutenção.

\footnotetext{
${ }^{96}$ SARMENTO, Daniel. Op. cit. p. 74.
} 


\section{CAPÍTULO IV - CRÍTICAS E EXEMPLOS}

\section{CRÍTICAS E POSSÍVEIS FALHAS NO MÉTODO}

A ponderação de interesses constitucionais, em uma primeira análise, mostra-se um método pouco ortodoxo no direito moderno, uma vez que "confere" ao intérprete a possibilidade de atribuir certa dose de discricionariedade à solução do caso concreto, mesmo que essa subjetividade esteja contida por um método pré-determinado.

Assim, a ponderação de interesses encontra na doutrina algumas críticas relativas a sua estrutura de atuação, onde, dentre os principais pontos de destaque, verificam-se: uma "relativização dos Direitos Fundamentais", uma possível "inconsistência no seu método de realização" e uma "quebra ao princípio da separação dos poderes". 97

A primeira objeção é a de que o método da ponderação, que é utilizado para superação de contradições entre direitos e valores fundamentais, implica um "esvaziamento" de referidos direitos e valores fundamentais. ${ }^{98}$

A grande crítica aqui refere-se à fragilidade atribuída aos direitos fundamentais, pois estes somente teriam sua aplicação plena se o Poder Judiciário "assim entendesse" no caso concreto. A possibilidade de restringir o cabimento e exercício pleno de um direito fundamental em função de outro violaria “o espírito da Constituição”, pois esta somente seria válida nos casos em que o Judiciário assim entendesse razoável e proporcional.

\footnotetext{
${ }^{97}$ Ibid. p., 141.

98 A crítica da "relativização dos direitos fundamentais pela ponderação" é defendida por juristas alemães - Peter Lerche e Richard Thoma - que entendem criar-se uma "reserva de ponderação", onde os direitos fundamentais seriam relativos e subordinados à ponderação. Cf. Ibid. p., 141 .
} 
Conforme o professor Sarmento, a ponderação de interesses mostra-se, entretanto, uma técnica fundamental para a solução dos aparentes embates constitucionais. A Constituição engloba diversos direitos fundamentais que, num mundo em constante movimento social, podem vir a colidir com a ponderação, os direitos restringidos ainda logram alguma eficácia, mesmo que contida no caso concreto, não tornando-se, porém, uma norma sem uso afastada do ordenamento jurídico - ao passo que, sem a ponderação, o aplicador do direito teria de promover uma hierarquia diante de um aparente embate, afastando um raciocínio crítico e razoável e instaurando algo como verdade absoluta.

A segunda crítica observada na doutrina concerne à "inconsistência metodológica" "99, ou seja, o método da ponderação conduziria a uma irracionalidade da decisão porque tornaria o procedimento decisório imprevisível, dependente do arbítrio do juiz.

Afirma-se que a ponderação não possui parâmetros concretos - critérios racionais e objetivos de decisão. Assim, o juiz estaria imbuído de uma discricionariedade maior do que lhe é legalmente conferida, atribuindo, por conseqüência, uma dose de insegurança à ordem jurídica. Tal crítica se apresenta aludindo que a ponderação seria uma forma de realizar uma imposição de decisões judiciais, sendo essa inconsistência uma "válvula de subjetividade" dos aplicadores do direito.

Contrapondo essa crítica, o professor Sarmento observa que os princípios da proporcionalidade e da razoabilidade formam a base da ponderação. O princípio da dignidade humana, bem como a necessidade de observar uma interpretação conforme a constituição, o limite material. Dessa forma, busca-se diminuir o quanto possível a subjetividade do aplicador do direito. Além disso, a fundamentação do magistrado deve ser pautada nos

\footnotetext{
${ }^{99}$ Seus maiores defensores são Wlather Murphy, James Flmin e Sotirios Barber. Cf. Ibid. p., 146.
} 
critérios expostos, juntamente com a apresentação de uma congruência entre a ponderação, os critérios usados e o resultado atingido.

Na terceira objeção - "quebra do princípio da separação dos poderes" afirma-se que a aplicação do método da ponderação por si é eivada de ilegitimidade porque "transforma" o juiz em legislador sem que tenha se submetido, como este último, ao processo democrático de escolha popular.

Alude-se a um "déficit" de legitimidade democrática no processo decisório. Por não serem representantes da vontade popular, uma vez que não foram eleitos, não deve ser transferido para o juiz o poder de realizar decisões de caráter político sobre os bens e valores tutelados pela norma. Assim, a crítica encontra-se em torno da legitimidade democrática das decisões fundamentadas na ponderação, pois o Judiciário assumiria às vezes do Legislativo.

Entretanto, Sarmento explica que, havendo uma norma infraconstitucional, o aplicador do direito deve utilizar-se desta, não podendo resolver o embate com seu entendimento subjetivo. O legislador, ao editar tal norma, realiza uma prévia ponderação acerca dos interesses sociais e políticos, cumprindo sua função precípua e afastando a ponderação por parte do Poder Judiciário. Assim, a ponderação não cria um "esvaziamento" do Poder Legislativo ou traz afronta ao princípio da separação dos poderes, pois, conforme afirma Daniel Sarmento, o uso do método de ponderação pressupõe a inexistência de regra legislativa específica resolvendo o conflito entre principios constitucionais $^{100}$, ou seja, o Judiciário somente utiliza a técnica da ponderação na ausência de norma que impere solução prática ao caso concreto.

\footnotetext{
${ }^{100}$ Ibid. p., 148.
} 
Ressalte ainda que cabe ao Judiciário o controle das normas editadas pelo Legislativo, sendo esta, entretanto, função diversa da ora tratada e plenamente legítima. ${ }^{101}$

Em suma, esse três pontos de objeção vistos são as principais críticas doutrinárias realizadas à ponderação, que, assim como qualquer tese de direito, deve mesmo possuir um contraponto crítico para sua improvisação. Não devendo a doutrina aceitar algo como verdade absoluta e descaracterizar um raciocínio lógico e razoável sobre o tema.

Diante do exposto, cumpre verificar como se opera no cotidiano jurídico a técnica da ponderação.

\section{CASOS CONCRETOS}

A exposição de uma visão prática do cotidiano jurídico, além de ilustrar, ajuda a compreender como ocorre a aplicação da técnica da ponderação de interesses nos tribunais. Apesar de não ser uma técnica da vasta aplicação pelo Poder Judiciário, recentes julgados podem ser citados e estudados. ${ }^{102}$

A ponderação foi suscitada pela Ministra Ellen Gracie no Recurso Extraordinário 208.685/RJ, onde o acórdão ficou assim ementado:

"Direito à informação (CF, art. 220). Dano moral. A simples
reprodução, pela imprensa, de acusação de mau uso de verbas públicas,
prática de nepotismo e tráfico de influência, objeto de representação
devidamente formulada perante o TST por federação de sindicatos, não

\footnotetext{
${ }^{101}$ Note-se que o judiciário sempre deve impor seu dever de guardião da constituição, verificando a constitucionalidade das leis, porém, não pode usar em demasia sua prerrogativa para privar ou restringir a competência do Poder Legislativo. O controle da constitucionalidade deve ser realizado antes da utilização da técnica da ponderação.

${ }^{102}$ Cumpre ressaltar que os exemplos utilizados aqui são concernentes ao ordenamento jurídico pátrio, não sendo analisada a jurisprudência alienígena. Conforme destaca Daniel Sarmento, a jurisprudência brasileira ainda encontra-se tímida quanto à aplicação da técnica da ponderação de interesses, afirmando, inclusive, que esta técnica "não vingou" nos tribunais do Brasil.
} 
constitui abuso de direito. Dano moral indevido. RE conhecido e provido".

Nesta oportunidade, o voto condutor do acórdão recorrido vislumbrava $\mathrm{o}$ conflito entre dois princípios fundamentais - o direito à informação e o direito à inviolabilidade da intimidade - entendendo que, no caso concreto em questão, este último encontra-se com maior importância relativa ao da liberdade de informação. Diante disso, a Ministra explicou em seu voto, dispondo in verbis:

\footnotetext{
"Impende observar, entretanto, que não há, na verdade, conflito entre os mencionados princípios constitucionais, mesmo porque não se resolve a suposta colisão entre dois princípios suprimindo um em favor do outro. A colisão será solucionada levando-se em conta o peso ou a importância relativa de cada um. A solução, portanto não pode deixar de lado os conhecidos princípios da razoabilidade e ponderação dos bens envolvidos." 103
}

$\mathrm{O}$ voto da Ministra reformando o acórdão foi acompanhado de forma unânime, demonstrando uma disparidade no que concerne ao entendimento dos aparentes conflitos constitucionais por parte dos tribunais e do Supremo Tribunal Federal.

Outro caso que também merece destaque por englobar a ponderação de interesses é o $H C$ 82.424/RS ${ }^{104}$, onde a discussão envolve princípios constitucionais aparentemente colidentes. O teor da ementa do STJ, que indeferiu o Habeas Corpus, dispõe o seguinte:

"CRIMINAL. HABEAS CORPUS. PRÁTICA DE RACISMO. EDIÇÃO E VENDA DE LIVROS FAZENDO APOLOGIA DE IDÉIAS PRECONCEITUOSAS E DISCRIMINATÓRIAS. PEDIDO DE AFASTAMENTO DA IMPRESCRITIBILIDADE DO DELITO. CONSIDERAÇÕES ACERCA DE SE TRATAR DE PRÁTICA DE RACISMO, OU NÃO. ARGUMENTO DE QUE OS JUDEUS NÃO SERIAM RAÇA. SENTIDO DO TERMO E DAS AFIRMAÇÕES FEITAS NO ACÓRDÃO. IMPROPRIEDADE DO WRIT. LEGALIDADE DA

\footnotetext{
${ }^{103}$ STF, Segunda Turma, RE 208.685 / RJ, Relatora Min Ellen Gracie, DJ 22-08-2003.

${ }^{104}$ STF, Pleno, HC 82.424 / RS, Relator Min Moreira Alves, DJ 19-03-2004.
} 
CONDENAÇÃO POR CRIME CONTRA A COMUNIDADE JUDAICA. RACISMO QUE NÃO PODE SER ABSTRAÍDO. PRÁTICA, INCITAÇÃO E INDUZIMENTO QUE NÃO DEVEM SER DIFERENCIADOS PARA FINS DE CARACTERIZAÇÃO DO DELITO DE RACISMO. CRIME FORMAL. IMPRESCRITIBILIDADE QUE NÃO PODE SER AFASTADA. ORDEM DENEGADA"

A questão versa sobre uma condenação penal em função da publicação de livros com características "anti-semitas", colocando em choque a liberdade de expressão e a dignidade da pessoa humana, dois princípios de hierarquia constitucional.

O Tribunal, por maioria, indeferiu o habeas corpus, vencidos os Ministros Moreira Alves, Marco Aurélio e Carlos Britto. Com interessante posição, cabe destacar o voto do Ministro Celso de Mello, que alude a dois pontos aqui estudados - impossibilidade de se verificar um "direito absoluto" e a ponderação em si - registrando em seu voto:

"Não há, no sistema constitucional brasileiro, direitos ou garantias que se revistam de caráter absoluto, mesmo porque razões de relevante interesse público ou exigências derivadas do princípio de convivência das liberdades legitimam, ainda que excepcionalmente, a adoção, por parte dos órgãos estatais, de medidas restritivas das prerrogativas individuais ou coletivas, desde que respeitados os termos estabelecidos pela própria constituição.

$O$ estatuto constitucional das liberdades públicas, ao delinear o regime jurídico a que estas estão sujeitas - e considerando o substrato ético que as informa - permite que sobre elas incidam limitações de ordem jurídica, destinadas, de um lado, a proteger a integridade do interesse social e, de outro, a assegurar a coexistência harmoniosa das liberdades, pois nenhum direito ou garantia pode ser exercido em detrimento da ordem pública ou com desrespeito aos direitos e garantias de terceiros. "105

O Ministro Celso de Mello alude à impossibilidade prática e fática de se observar um direito "intocável”, explicando que em alguns casos far-se-á necessária a observação de uma imposição restritiva, seja para proteger o

\footnotetext{
${ }^{105}$ STF, Pleno, HC 82.424 / RS, Min Celso de Mello, DJ 19-03-2004, citando trecho de RTJ 173/805810, 807-808, Min. Rel. Celso de Mello, Pleno.
} 
interesse social, seja para assegurar a harmonia e o exercício das liberdades. Ainda em seu voto assevera o Ministro:

“...cabe reconhecer que os postulados da dignidade e da igualdade pessoal dos seres humanos constituem limitações externas a liberdade de expressão, que não pode, e não deve, ser exercida com o propósito subalterno de veicular práticas criminosas, tendentes a fomentar e a estimular situações de intolerância e de ódio público.

Entendo que a superação dos antagonismos existentes entre princípios constitucionais há de resultar da utilização, pelo Supremo Tribunal Federal, de critérios que lhe permitam ponderar e avaliar, 'hic et nunc', em função de determinado contexto e sob uma perspectiva axiológica concreta, qual deva ser o direito a preponderar no caso, considerada a situação de conflito ocorrente, desde que, no entanto, a utilização do método da ponderação de bens e interesses não importe em esvaziamento do conteúdo essencial dos direitos fundamentais, tal como adverte o magistério da doutrina (...).

Isto significa, em um contexto de liberdades aparentemente em conflito, que a colisão dele resultante há de ser equacionada, utilizandose, esta corte, do método - que é apropriado e racional - da ponderação de bens e valores, de tal forma que existência de interesse público na revelação e no esclarecimento da verdade, em torno de supostas ilicitudes penais praticadas por qualquer pessoa basta, por si só, para atribuir, ao Estado, o dever de atuar na defesa de postulados essenciais, como o são aqueles que proclamam a dignidade da pessoa humana e a permanente hostilidade contra qualquer comportamento que possa gerar o desrespeito a alteridade...".

Percebe-se a técnica da ponderação em sua plena forma no voto do Ministro, onde este alude à Dignidade da Pessoa Humana como um limite à ponderação ao exercício dos demais direitos constitucionais. Ressalta ainda a necessidade de uma observação do caso concreto, determinando o contexto e a perspectiva axiológica onde incidirá a ponderação, atentando para o cuidado de ocorrência de um esvaziamento do conteúdo essencial dos direitos fundamentais.

Afora os casos expostos, outro ponto bastante discutido na doutrina refere-se às provas processuais ilícitas, ilegítimas e suas derivações. 
Conforme explica Fernando $\mathrm{Capez}^{106}$ a prova é considerada ilícita sempre que for produzida com afronta a norma de direito material, ou seja, são ilícitas as provas produzidas mediante a prática de crime ou contravenção, ou ainda, as obtidas através de uma violação das normas de direito civil, comercial, ou qualquer outro ramo do Direito. Explica também que as provas são ilegítimas se essa violação das normas possuir uma natureza processual. Alude ainda o autor às provas derivadas das ilícitas e das ilegítimas - lícitas em si mesmas, mas produzidas a partir de um fato ilícito - entrando em um ponto bastante fomentado pela doutrina.

Grande discussão da doutrina gira em torno do cabimento ou não das provas ilícitas por derivação no processo, ${ }^{107}$ surgindo inclusive, a doutrina do "fruit of the poisonous tree" ou "fruit doctrine" - fruto da árvore envenenada ${ }^{108}$ - onde se dispõe que as provas lícitas obtidas através de ilícitas, também estariam "contaminadas" em sua base de fundamentação de ilegalidade, não devendo ser aplicadas portanto.

O posicionamento da doutrina majoritária é no sentido de que não há que se falar em conflito de direitos e garantias fundamentais, cabendo a ponderação apurar o cabimento "pro reo" - aceitação quase unânime na doutrina - ou "pro societate".

Fernando Capez entende que a ponderação "pro societate" também deve ser observada, bastando uma análise crítica dos valores em contraste. ${ }^{109}$

Interessante destacar por fim uma divergência de aplicação que pôde ser observada nos tribunais pátrios.

\footnotetext{
${ }^{106}$ CAPEZ, Fernando. "Curso de Processo Penal”. $11^{\mathrm{a}}$ ed. Saraiva, São Paulo, SP, 2004, p., 261-270.

${ }^{107}$ Vale citar o artigo 5 $5^{\circ}$, LVI, CF/88. "são inadmissiveis, no processo, as provas obtidas por meios ilícitos".

${ }^{108}$ Doutrina que surge nos EUA em 1914 e repercute no ordenamento jurídico pátrio, sendo inclusive, a posição adotada pelo STF atualmente. Cf. FILHO, Fernando da Costa Tourinho. "Manual de Processo Penal”. $4^{\mathrm{a}}$ ed. Saraiva, São Paulo, SP, 2002, p., 451-458.

${ }^{109}$ CAPEZ, Fernando. Op. cit. p., 269.
} 
O STF, no RE no $251.445 / \mathrm{GO}$, assentou o não cabimento da ponderação

no tocante às provas derivadas de ilícitas, constando da decisão:

"Cabe ter presente, ainda, que o princípio da proporcionalidade não pode converter-se em instrumento de frustração da norma constitucional que repudia a utilização, no processo, de provas obtidas por meios ilícitos. Esse postulado, portanto, não deve ser invocado indiscriminadamente, ainda mais quando se acharem expostos, a clara situação de risco, direitos fundamentais assegurados pela Constituição, como ocorre na espécie ora em exame, em que se decidiu, na esfera do tribunal a quo, que a prova incriminadora dos ora recorridos foi produzida, na causa penal, com ofensa às cláusulas constitucionais que tutelam a inviolabilidade domiciliar e preservam a garantia da intimidade. "110

Com isso, o STF afasta a possibilidade de se realizar uma ponderação acerca das provas derivadas de ilícitas no que concerne a uma face "pro societate" de sua aplicação.

Entretanto, o STJ já se pronunciou de forma oposta ${ }^{111}$, sob a seguinte argumentação:

"O inciso LVI do art. $5^{\circ}$ da Constituição, que fala que 'são inadmissiveis...
as provas obtidas por meio ilícito' não tem conotação absoluta. Há
sempre um substrato ético a orientar o exegeta na busca de valores
maiores na construção da sociedade. A própria Constituição Federal
Brasileira, que é dirigente e programática, oferece ao juiz, através da
'atualização constitucional' (Verfassungsaktualisierung) base para o
entendimento de que a cláusula constitucional invocada é relativa. A
jurisprudência americana, mencionada em precedente do Supremo
Tribunal Federal, não é tranqüila. Sempre é invocável o princípio da
'razoabilidade' (Reasonableness). O principio da exclusão das provas
ilicitamente obtidas (Exclusionary Rule) também lá pede
temperamentos."
(112

O STJ não encontra no citado artigo constitucional um direito absoluto, afirmando caber uma ponderação, inclusive "pro societate", no que concerne à

\footnotetext{
${ }^{110}$ Apud, SARMENTO, Daniel. Op. cit. p., 181.

${ }^{111}$ HC 3.982/RJ, Rel. Min. Adhemar Maciel, 6 ${ }^{\mathrm{a}}$ Turma, DJU 26-02-96, p. 4.084.

${ }^{112}$ Apud, SARMENTO, Daniel. Op. cit. p., 181.
} 
apuração de provas derivadas de ilícitas nos casos concretos, divergindo, como visto, do STF.

Diante do exposto verifica-se que a técnica da ponderação de interesses, cada vez mais, recebe a devida atenção do Judiciário, analisando os casos concretos de forma crítica e coesa. 


\section{CAPÍTULO V - CONCLUSÃO}

\section{CONCLUSÃO}

Nossa sociedade encontra-se em constante evolução, onde as idéias estão sempre em um fluxo acelerado de mutação. O direito, enquanto regulador social, deve prestar-se a realizar uma adaptação aos novos entendimentos, compondo em seu ordenamento os conceitos e as concepções sociais, assim, inserindo em sua Lei Maior a proteção aquiescida aos novos interesses.

Diante da necessidade de adequação a tal pluralismo social, não é difícil imaginar o surgimento de confrontos entres os interesses protegidos pela Lei Suprema, cabendo ao aplicador do direito o compromisso de harmonizar e interpretar a constituição como um todo, seguindo, para tanto, o princípio básico da unidade e o método da interpretação conforme a Constituição.

Com a tentativa frustrada de uma harmonização das normas constitucionais, surge um entrave para o qual a Constituição não dispõe regra específica, encontrando-se, o intérprete, com a missão de resolver um conflito sem parâmetros para tanto.

Com a observância exclusiva dos métodos tradicionais de solução de conflitos normativos - cronológico, hierárquico e especialidade - seria impossível resolver os aparentes embates constitucionais. Pois as normas, dentro da própria Constituição, não podem sofrer "conceituações" que as definam como anteriores ou superiores frente a outras normas mesmo nível hierárquico. Como visto, essas classificações somente podem ser observadas se o intérprete comparar uma norma Constitucional com uma norma infraconstitucional, verificando-se então, um escalonamento do ordenamento jurídico. 
Dessa forma, nota-se que o aplicador do direito, sem a técnica da ponderação de interesses, não encontraria maneira de solucionar um embate de normas constitucionais. Assim, restar-lhe-ia, o afastamento de uma das normas ou sua completa supressão, agindo de modo absolutamente subjetivo, pois também não teria parâmetros procedimentais que definissem qual norma sofreria restrição.

Para que tanto não ocorra, o método da ponderação de interesses socorre o exegeta que se vê diante de tal problema.

Com os princípios da proporcionalidade e da razoabilidade formando sua base, a técnica da ponderação encontra uma fundamentação, um alicerce.

Com a necessidade da observância por parte do aplicador do direito de uma atuação restrita ao que ultrapassar os "limites imanentes", seguindo ainda o princípio da Dignidade Humana e o método da "interpretação conforme a Constituição", a técnica da ponderação encontra seus limites.

Com o princípio constitucional da necessidade de uma fundamentação das decisões judiciais, a técnica da ponderação encontra uma forma de controle, interno - realizado pelos aplicadores do direito - e externo realizado pela população de uma maneira geral.

Assim, a ponderação de interesses mostra-se como uma técnica bastante apropriada no que concerne à solução de um aparente conflito da Norma Fundamental.

Apesar disso, a ponderação não escapa as críticas doutrinárias, que suscitam três problemas - "relativização dos direitos fundamentais", "inconsistência metodológica" e "quebra ao princípio da separação dos poderes".

A doutrina afirma que, com a utilização da ponderação, o intérprete estaria realizando uma "relativização dos direitos fundamentais", um "esvaziamento" de suas garantias, uma vez que o Poder Judiciário "poderia" deixar de atribuir plena eficácia, se assim entendesse diante do caso concreto. 
Seguinte a isso, a doutrina alude a uma "inconsistência metodológica", enfatizando tratar-se de uma técnica sem parâmetros procedimentais coerentes, trazendo em suas decisões uma insegurança jurídica, pois a prestação jurisdicional estaria sujeita ao sentimento e a subjetividade do juiz.

Como um desdobramento das duas primeiras críticas, a doutrina entende que a técnica da ponderação fere o princípio da separação dos poderes, pois os juízes estariam agindo como legisladores, uma vez que, a estes seria "concedida" a faculdade de aplicar ou não a lei.

Mesmo diante das considerações expostas, a ponderação de interesses conforme todos os critérios aqui estudados - mostra-se uma técnica bastante racional e razoável, merecendo um enfoque crítico que vise um melhoramento ainda maior de seus procedimentos.

No Brasil, consoante o observado com casos reais, ainda é modesta a aplicação por parte da jurisprudência, diferentemente do observado em países como os Estados Unidos da América e a Alemanha, onde pode se verificar uma ampla utilização da técnica da ponderação de interesses.

Não se espera, com o método estudado, alcançar uma técnica que se mostre como verdade absoluta para a solução de embates constitucionais. Com a exposição realizada, tentou-se trazer uma análise acadêmica, com o intuito de fomentar uma discussão jurídica sobre um tema de tamanha importância e relevância social. 


\section{BIBLIOGRAFIA}

ALVIM, José Eduardo Carreira. Teoria Geral do Processo. Rio de Janeiro, Forense Universitária, 2002.

ÁVILA, Humberto. Teoria dos Princípios - da Definição à aplicação dos princípios jurídicos. São Paulo, Malheiros editora, 2004.

BARRETO, Vicente. Interpretação constitucional e Estado Democrático de Direito. Revista de Direito Administrativo, RJ, nº 203, 1996.

BARROSO, Luís Roberto. Interpretação e Aplicação da Constituição Fundamentos de uma Dogmática Constitucional Transformadora. São Paulo, Saraiva, 2004.

BOBBIO, Norberto. Teoria da Norma Jurídica. São Paulo, Bauru, Edipro, 2003.

editora 1994.

- Teoria do Ordenamento Jurídico. Brasília, UnB

. O Positivismo Jurídico - Lições de Filosofia do Direito. São Paulo: Ícone, 1995.

BONAVIDES, Paulo. Curso de Direito Constitucional. São Paulo, Malheiros editora, 2004.

CAPEZ, Fernando. Curo de Processo Penal. São Paulo, Saraiva, 2004.

CASTRO, Flávia de Almeida Viveiros de. Interpretação Constitucional e Prestação Jurisdicional. Rio de Janeiro, Lumen Juris, 2000.

CAVALCANTI, Arthur José Faveret. A estrutura lógica do Direito. Rio de Janeiro, Renovar, 2003. 
COBRA, Rubem Q. Immanuel Kant. Brasília, 1997. Disponível em $<$ http://www.cobra.pages.nom.br/fmp-kant.html $>$. Acesso em: 28 abril 2005.

DALLARI, Dalmo de Abreu. Elementos de Teoria Geral do Estado. São Paulo, Saraiva, 2000.

DANTAS, Ivo. Princípios Constitucionais e Interpretação Constitucional. Rio de Janeiro, Lumen Juris, 1995.

DINIZ, Maria Helena. Conflito de Normas. São Paulo, Saraiva, 1998. Saraiva, 1992. . Norma Constitucional e Seus Efeitos. São Paulo,

DWORKIN, Ronald. Los Derechos en Serio. Córcega, Barcelona, Ariel S.A., 1995.

FILHO, Fernando da Costa Tourinho. Manual de Processo Penal. São Paulo, Saraiva, 2002.

JÚNIOR, Humberto Theodoro. "Curso de Direito Processual Civil". Volume I, $39^{\mathrm{a}}$ ed. Forense RJ, 2003.

LARENZ, Karl. Metodologia de La Ciência Del Derecho. Córcega, Barcelona, Ariel S.A., 1966.

PAULI, Evaldo. Micro História da Filosofia. Universidade Federal de Santa Catarina, $1997 . \quad$ Disponível em $<$ http://www.educ.fc.ul.pt/docentes/opombo/hfe/momentos/escola/sofi stas/protagoras.htm>. Acesso em: 28 abril 2005.

PEIXINHO, Manuel Messias. A Interpretação e os Princípios Fundamentais - Elementos para uma Hermenêutica Constitucional Renovada. Rio de Janeiro, Lumen Juris, 2000.

PEIXINHO, Manoel Messias. GUERRA, Isabella Franco. FILHO, Firly Nascimento. Os Princípios da Constituição Federal de 1988. Rio de Janeiro, Lumen Juris, 2001. 
PINTO, Carlos Alberto da Mota. Teoria geral do direito civil. Coimbra Editora, $3^{\mathrm{a} e d .,} 1985$.

REALE, Miguel. Lições Preliminares de Direito. São Paulo, Saraiva, 1999.

RIBERA, Willman Ruperto Durán. Los Principios de la Constitución Boliviana. Tribunal Constitucional de Bolívia, 2003. Disponível em $<$ http://www.tribunalconstitucional.gov.bo/ArticuloId-32.html $>$. Acesso em: 05 maio 2005.

SARMENTO, Daniel. A Ponderação de Interesses na Constituição Federal. Rio de Janeiro, Lumen Juris, 2002.

SILVA, José Afonso da. Curso de Direito Constitucional Positivo. São Paulo: Malheiros editora, 2001.

SIMÕES, Reinerio L. M. Filosofia e Direito no Pensamento Antigo. UniverCidade/UCB, 2001. Disponível em $<$ http://www.reinerio.hpg.ig.com.br/Sofistas.htm $>$. Acesso em: 28 abril 2005.

TEIXEIRA, J. H. Meirelles. Curso de Direito Constitucional. Rio de janeiro, Forense Universitária, 1991. 